\title{
Source apportionment of fine PM by combining high time resolution organic and inorganic chemical composition datasets
}

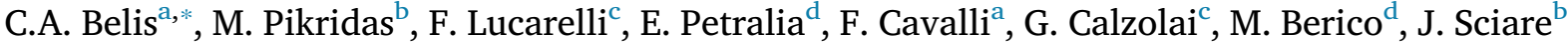 \\ ${ }^{a}$ European Commission, Joint Research Centre Via Fermi 2749, 21027, Ispra, Italy \\ ${ }^{\mathrm{b}}$ The Cyprus Institute, The Cyprus Institute $20 \mathrm{~K}$, Kavafi Street 2121, Aglantzia, Nicosia, Cyprus \\ ${ }^{\mathrm{c}}$ Department of Physics and Astronomy and I.N.F.N., Firenze, Italy \\ d ENEA - Italian National Agency for New Technologies, Via Martiri di Monte Sole 4, 40129, Bologna, Italy
}

\section{H I G H L I G H T S}

- High time resolution organic and inorganic data pose challenges for receptor models

- Inorganic ions, carbonaceous species and trace elements were measured in N Italy.

- A multistep approach led to PMF results consistent with off-line and on-line datasets.

- The combined dataset led to the identification of more sources.

- Source profiles with 87 species were consistent with external data and literature.

\section{A R T I C L E I N F O}

\section{Keywords:}

Source apportionment

Particulate matter

Po valley

Receptor models

Positive matrix factorization

On-line measurements

\begin{abstract}
A B S T R A C T
The use of high time resolution datasets of aerosol organic and inorganic species as input for receptor models poses a number of challenges. The estimation of uncertainties differ between different analytical methods and the number of chemical species may considerably vary among the different techniques. In this study, an approach to harmonise the uncertainties of different online datasets for their combined use in source apportionment with positive matrix factorization (PMF) is presented. The concentration of inorganic ions, organic fragments and trace elements were measured in a Po Valley background site using offline and online methods. Sixhour PM 2.5 samples were collected on filters and chemical analyses were carried out offline. Parallel hourly online measurements were made using the Xact 625 (CES LLC) XRF analyser and the Q-ACSM (Aerodyne Research Inc.) spectrometer.

Online and offline methods produced comparable results for the major chemical component and some trace elements, while others ( $\mathrm{Ba}, \mathrm{Ni}$, As and $\mathrm{Se}$ ) showed limited comparability between the two methods. To ensure the consistency of the final PMF results, a multistep approach was adopted. In the first step PMF was run with only the offline dataset, in the second step only the online organic data were used and in a third step the PMF run was executed using only the online inorganic species. In the first three steps running PMF with homogeneous data made it possible to identify the main sources and produce chemical profiles to be used as internal reference for the final fourth step in which all the online species (major inorganic ions, $\mathrm{m} / \mathrm{z}$ of organic fragments and trace elements) were combined. The sources of the final solution were developed using internally consistent chemical profiles and those from the literature and were validated by analysing the source diurnal variations and by comparison with external tracers. The sources identified were: biomass burning, aged biomass burning, secondary ammonium nitrate and ammonium sulphate, traffic, steel industry and waste thermal treatment. The source profiles with a large set of organic and inorganic species (87) and associated source diurnal variations resulting from this study are expected to serve as reference for future studies.
\end{abstract}

\footnotetext{
* Corresponding author.

E-mail address: claudio.belis@ec.europa.eu (C.A. Belis).
} 


\section{Introduction}

Ambient air particulate matter (PM) impacts both human health (Lelieveld et al., 2015) and the global climate (Baker and Peter, 2008; Leibensperger et al., 2012; Myhre et al., 2013). Main direct PM climate effects are a consequence of scattering part of the solar radiation back to space while its indirect climate effects are associated with the formation of clouds containing an increased number of smaller droplets (Haywood and Boucher, 2000; Lohmann and Feichter, 2004). Moreover, particles with aerodynamic diameter smaller than $2.5 \mu \mathrm{m}\left(\mathrm{PM}_{2.5}\right)$ are associated with "all-cause" lung cancer and cardiopulmonary mortality (Pope et al., 2002). Ambient PM originates from several sources that are either directly emitted into the atmosphere or formed from precursor gases by different mechanisms, such as nucleation and condensation (Kulmala et al., 2004). Once in the air, these particles undergo chemical transformations that alter their physical properties as well (Kanakidou et al., 2005; Seinfeld and Pandis, 2016).

In order to help establishing mitigation strategies concerning PM, sources of pollution should be identified and apportioned. Although chemical markers may help with the identification of certain sources, such as biomass burning, sea spray and dust particles (Guieu et al., 2002; Ovadnevaite et al., 2012; Simoneit et al., 1999), the general case is that each source has a distinct chemical profile and time trend that cannot be directly distinguished from co-emitted sources. One of the methods to apportion PM to its sources is receptor modelling (RM). The most common RMs are based on factor analysis of observed variables weighted by their uncertainty (Hopke, 2009; Watson et al., 2008).

Routine RM analyses are carried out using datasets consisting of $24 \mathrm{~h}$ filter samples. In Europe the choice of this time step partly derives from the need to align the sampling set up with the reference method for the determination of $\mathrm{PM}_{2.5}$ and $\mathrm{PM}_{10}$ mass (EN12341, 2014). The length of the sampling time when collecting particulate matter with low volume samplers (16-381/min flow) to accomplish its full chemical characterisation is also dictated by the need to collect enough material to quantifying components that are present in very low concentrations (e.g. trace elements, organic markers).

A study on the effect of the sampling time on the ability of factor analytical methods to resolve source types concluded that reducing the sampling duration can increase the number of sources identified by the model (Lioy et al., 1989). Time resolutions higher than $24 \mathrm{~h}$ make it possible to detect short-lived processes that determine or influence the release, formation and dispersion of pollutants into the atmosphere. Moreover, diurnal variations in sources give useful information for the identification of sources when using factor analytical tools that support the evaluation of it soundness from the physical point of view. For instance, traffic emissions are expected to peak during the rush hours, while those from biomass/wood burning take place mainly in the evening (Viana et al., 2013). Hourly or even higher resolution organic and major ions concentrations in fine PM determined with spectrometric methods is a well-established methodology that has been extensively used for source identification purposes (Jayne et al., 2000; Ng et al., 2011). On the other hand, trace elements are generally measured offline using filter-based samples or continuous samplers like streakers or rotating drums (Crilley et al., 2017; Lucarelli et al., 2018). Nevertheless, online (near real time) highly time resolved trace element information is less common (e.g. Furger et al., 2017; Visser et al., 2015; Tremper et al., 2018) and the evaluation of this kind of data is needed in order to understand whether it could be successfully used in source apportionment studies. Thanks to recent advancements in instrumentation, the availability of continuous and high time resolved organic fragments, ions and elements could open the way for a more reliable source identification which in addition could be partially automated to deliver near real time source contribution estimations, therefore, available to support the decisions of air quality managers in the short term.

A number of source apportionment studies based on trace elements high resolution time series (Park et al., 2014; Fang et al., 2015; Chang et al., 2018; Yu et al., 2018) have been recently published. However, few receptor modelling studies combining the organic and inorganic (both ions and trace elements) fractions of high time resolution aerosol datasets are currently available (Sofowote et al., 2018; Jeong et al., 2019). The reason is that such kind of analysis poses a number of challenges. Firstly, the combination of data from instruments with different operating principles that use different methods to estimate the uncertainties is required. Secondly, the instruments may not sample the same PM size fraction. In addition, the resulting factor chemical profiles are more complex than those currently available in the literature (higher number and type of species/markers) and therefore more difficult to interpret and validate in terms of sources and processes. The objective of this study is to develop a methodology for the combined use of hourly resolved organic and inorganic datasets with heterogeneous uncertainties for their use in source apportionment, in order to find an approach to deal with such issues.

\section{Data collection and methods}

A sampling campaign was carried out in January-February 2015 in a background monitoring site located in a small town (Veggiano) near Padua, Italy (Fig. 1). The site is a typical example of background location in the Po Valley with high PM levels, especially during winter time (Larsen et al., 2012; Vecchi et al., 2009). The concentration of 20 trace elements (Ca, Ti, V, Cr, Mn, Fe, Co, Ni, Cu, Zn, As, Se, Ag, Cd, Sn, $\mathrm{Sb}, \mathrm{Ba}, \mathrm{Hg}, \mathrm{Tl}$, and $\mathrm{Pb}$ ) in $\mathrm{PM}_{2.5}$ was determined by online $\mathrm{X}$ ray fluorescence using the Xact ${ }^{\circledR} 625$ (Cooper Environmental Services LLC) instrument. A co-located quadrupole aerosol chemical speciation monitor (Q-ACSM; Aerodyne Research Inc.) was used to analyse main ions $\left(\mathrm{SO}_{4}{ }^{2-}, \mathrm{NO}_{3}{ }^{-}, \mathrm{NH}_{4}{ }^{+}, \mathrm{Cl}^{-}\right)$and mass fragments ranging from 12 to 100 mass-to-charge ratio $(\mathrm{m} / \mathrm{z})$ of the non-refractory $\mathrm{PM}_{1}$ organic fraction $\left(\mathrm{NR}-\mathrm{PM}_{1}\right.$ ). In addition, parallel offline $\mathrm{PM}_{2.5}$ 6-h samples were collected on quartz filters (Pall QAT2500) using a low volume automatic sampler (Thermo FH95) between January 26th and February 19th. Because of the considerable effort needed to collect 6-h samples and obtain a complete $\mathrm{PM}_{2.5}$ chemical characterisation, the offline data collection was limited to 61 samples distributed along the monitoring campaign. The filter mass was determined using the European gravimetric reference method (EN12341, 2014). The trace elements (Ca, Ti, $\mathrm{V}, \mathrm{Cr}, \mathrm{Mn}, \mathrm{Fe}, \mathrm{Ni}, \mathrm{Cu}, \mathrm{Zn}, \mathrm{As}, \mathrm{Se}, \mathrm{Br}, \mathrm{Rb}, \mathrm{Sr}, \mathrm{Zr}, \mathrm{Mo}, \mathrm{Ba}$ and $\mathrm{Pb}$ ) in the off-line samples were analysed using particle induced X-ray emission (PIXE) and particle induced gamma-ray emission (PIGE) was used for $\mathrm{Al}$ (Calzolai et al., 2010).

Main ions $\left(\mathrm{Cl}^{-}, \mathrm{NO}_{3}{ }^{-}, \mathrm{SO}_{4}{ }^{2-}, \mathrm{C}_{2} \mathrm{O}_{4}{ }^{2-}, \mathrm{Na}^{+}, \mathrm{NH}_{4}^{+}, \mathrm{K}^{+}, \mathrm{Mg}^{2+}\right.$, $\mathrm{Ca}^{2+}$ ) were analysed by ion chromatography with electrochemical eluent suppression (ICS2000; Putaud et al., 2018). In 2015, the laboratory successfully participated in the EMEP33 inter-laboratory comparison using the described technique (https://www.nilu.no/ projects/ccc/intercomparison/index.html), with observed deviations of less than $\pm 15 \%$ of the assigned value for all ions except $\mathrm{K}^{+}$that showed deviation between $\pm 15-25 \%$ of the assigned value. Organic and elemental carbon (OC/EC) were analysed using a Sunset Dual-optical Lab Thermal-Optical Carbon Aerosol Analyse implementing the EUSAAR-2 thermal protocol (Cavalli et al., 2010; EN16909, 2017). In 2015, the laboratory successfully participated in the ACTRIS OC/EC inter-laboratory comparison using the same techniques as this study (http://www.actris-ecac.eu/ocec-analyse.html). Organic carbon and elemental carbon deviated, on average, by less than $-2 \%$ and $-15 \%$, respectively of the assigned value.

The $\mathrm{PM}_{2.5} 6 \mathrm{~h}$ samples and blank filters were conditioned for at least two days prior to weighing under stable environmental conditions, at $50 \%$ relative humidity and $20{ }^{\circ} \mathrm{C}$. The filters were weighed with a 1- $\mu \mathrm{g}$ resolution microbalance (Mettler Toledo, Switzerland, Model AX26) following the procedure of EN 12341. The balance was calibrated yearly using mass standards (class-E1, from Mettler Toledo, 


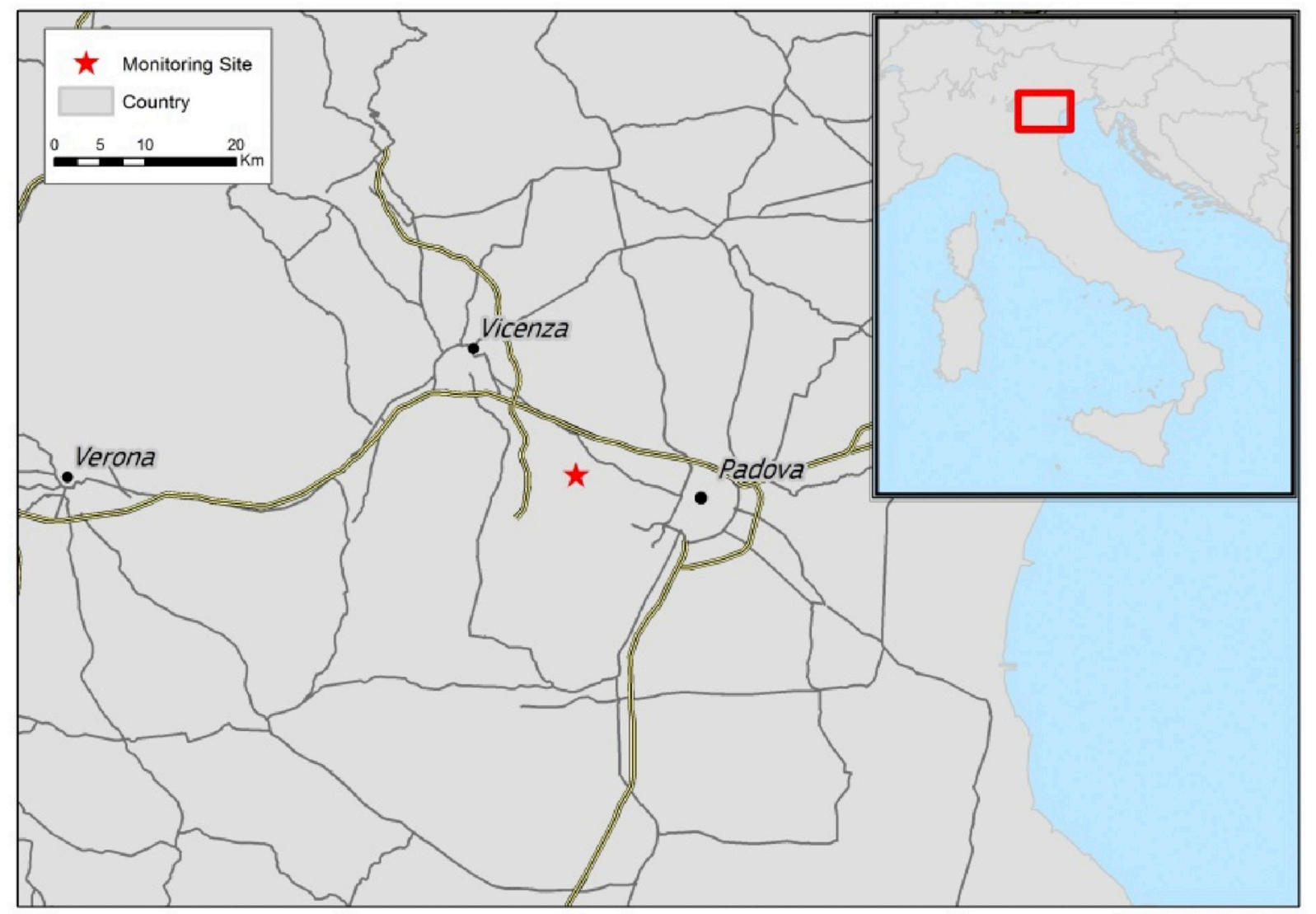

Fig. 1. Monitoring site location in the Po Valley.

Switzerland) and drift checks were performed with standard weights (class-E2 from Mettler Toledo, Switzerland) before weighing. Field blanks were used to check the stability in the sampling conditions and identify possible artefacts.

\subsection{Methods used for trace elements determination}

The Energy Dispersive X-ray fluorescence technique (ED-XRF) has been extensively used for off-line analysis of trace elements in PM (Brown et al., 2010; Niu et al., 2010; Yatkin et al., 2012). The Xact 625 used in this study implements this technique for online measurements (Geiger et al., 2015; Furger et al., 2017; Tremper et al., 2018). To that end, it collects PM samples on a Teflon tape filter at a $16.71 / \mathrm{min}$ flow and subsequently accomplishes the analysis in the sampled spot on the tape while the next sample is being collected on another area of the same tape. In this study, the sampling intervals were configured to provide $1 \mathrm{~h}$ average concentrations. The instrument was calibrated by comparison with NIST reference standards. To optimise the measurement efficiency in the Xact 625 the intensity of X-rays was adjusted to the amount of element present in the sample by means of known element specific sensitivity curves pre-determined with standards. The following automated and manual QA procedures were implemented in Xact 625: a) Pd rod calibration for every sample, b) daily energy alignment and upscale tests (at midnight), and c) periodic checks with NIST traceable thin film standards, and flow and blank tests. Even though the Xact 625 uncertainty is related to the size of the peak which goes through spectral deconvolution for determining the concentrations, the uncertainty depends only partially on the concentration of the measured element because other factors influence the measure (section 3.1).

A 3 MV Tandetron (High Voltage Engineering Europa B.V.) accelerator was used for PIXE and PIGE analyses. Samples were bombarded by a $2 \mathrm{~mm}^{2}$ proton beam of $3 \mathrm{MeV}$ that was extracted in air through a thin $(500 \mathrm{~nm}) \mathrm{Si}_{3} \mathrm{~N}_{4}$ window. An array of two KETEK GmbH silicon drift detectors (SDDs), with $113 \mathrm{~mm}^{2}$ area and $450 \mathrm{~mm}$ thickness, shielded by $450 \mathrm{~mm}$ Mylar foils, detect X-rays in the range $3-20 \mathrm{keV}$. Currents of the order of $100 \mathrm{nA}$ were applied and measurements lasted $120 \mathrm{~s}$ for each sample. A further SDD detector with thin entrance window $(8 \mu \mathrm{m}$ $\mathrm{Be}$ ) and He flow in front of it was implemented for the detection of Xrays in the range 1-6 keV. This modification allowed the detection of all the elements down to Na with good sensitivity on most collection substrata (Lucarelli et al., 2014). Since the detector does not work efficiently with quartz fibre filters, due to the high Si X-ray counting rate from the filter itself, PIGE (Particle Induced g-ray Emission) was exploited for the quantification of Al. PIGE and PIXE measurements were performed simultaneously with the same beam and duration conditions. The $\gamma$-rays were measured using a $60 \times 23 \mathrm{~mm}$ coaxial Ge detector (Calzolai et al., 2010).

PIXE spectra were fitted using the GUPIX code and elemental concentrations were obtained by a calibration curve from a set of thin standards (Micromatter Inc.) of known areal density (uncertainty: 5\%). PIGE spectra were fitted using a standard Gaussian fitting routine and $\mathrm{Al}$ elemental concentrations were obtained by comparison with the $\gamma$ ray yield from a thin $\mathrm{Al}$ standard (Micromatter Inc.) of known areal density. A check of the calibration was routinely performed analysing the NIST SRM2783 (Air Particulate on Filter Media). The reported PIXE and PIGE uncertainties include the statistical and spectra-fit procedure plus a $5 \%$ attributable to the uncertainty of the certified areal density of the standards used to compute the calibration curve.

In Table 1 the method detection limits (MDLs) and percentage of values below detection and quantification limits (MQLs) are given for each element. The differences in the MDLs of the two techniques are due to the more stringent approach adopted in the PIXE/PIGE method. The Xact 625 calculates them as $1 \sigma$ of the interference free detection 
Table 1

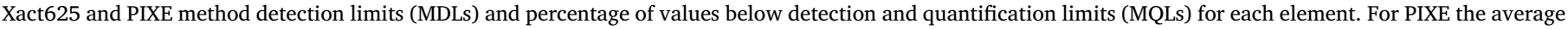
is provided because MDLs are specific for every measurement. The quantification limits are calculated as $3 \mathrm{x}$ MDL.

\begin{tabular}{|c|c|c|c|c|c|c|c|c|c|c|c|c|c|c|c|c|c|c|c|c|c|c|}
\hline & TYPE & UNITS & $\mathrm{Ca}$ & $\mathrm{Ti}$ & $\mathrm{V}$ & $\mathrm{Cr}$ & $\mathrm{Mn}$ & $\mathrm{Fe}$ & Co & $\mathrm{Ni}$ & $\mathrm{Cu}$ & $\mathrm{Zn}$ & As & Se & $\mathrm{Ag}$ & $\mathrm{Cd}$ & Sn & $\mathrm{Sb}$ & $\mathrm{Ba}$ & $\mathrm{Hg}$ & $\mathrm{Tl}$ & $\mathrm{Pb}$ \\
\hline Xact 625 MDL $(1 \sigma)$ & $1 \mathrm{~h}$ & $\mathrm{ng} / \mathrm{m}^{3}$ & 0.9 & 0.4 & 0.3 & 0.3 & 0.3 & 0.8 & 0.3 & 0.2 & 0.3 & 0.2 & 0.1 & 0.1 & 4.3 & 5.7 & 7.5 & 0.7 & 0.9 & 0.2 & 0.2 & 0.3 \\
\hline BDL & & $\%$ & 0 & 1 & 8 & 6 & 0 & 0 & 68 & 0 & 0 & 0 & 42 & 7 & 0 & 0 & 0 & 5 & 59 & 0 & 97 & 0 \\
\hline BQL & & $\%$ & 0 & 21 & 68 & 41 & 6 & 0 & 100 & 21 & 0 & 0 & 53 & 75 & 98 & 98 & 82 & 7 & 95 & 18 & 100 & 0 \\
\hline PIXE MDL $(3 \sigma)$ & average & $\mathrm{ng} / \mathrm{m}^{3}$ & 7.4 & 3.2 & 2.2 & 1.4 & 1.2 & 0.9 & & 0.6 & 0.7 & 0.7 & 0.6 & 0.5 & & & & & 11.6 & & & 1.9 \\
\hline BDL & & $\%$ & 0 & 2 & 76 & 0 & 2 & 0 & & 0 & 0 & 0 & 51 & 95 & & & & & 14 & & & 10 \\
\hline BQL & & $\%$ & 0 & 65 & 98 & 11 & 3 & 0 & & 2 & 2 & 0 & 94 & 100 & & & & & 52 & & & 35 \\
\hline
\end{tabular}

limit while in PIXE/PIGE are computed as $3 \sigma$ of the background areas over a 1 FWHM (Full Width Half Maximum) region centred on the element's principal peak centroid in the spectra (therefore, PIXE MDLs are specific for every sample and element). In case of standard daily samples or hourly samples collected with devices developed for that purpose such as the streaker sampler, PIXE DLs are roughly $50 \%$ those of Xact (Calzolai et al., 2015).

\subsection{Method used for organic composition determination}

A Q-ACSM with unit mass resolution (UMR) and time steps of $30 \pm 1 \mathrm{~min}$ was used to analyse the NR-PM $\mathrm{P}_{1}$. The operation principle is based on impacting a focused particle beam onto a heated $\left(600^{\circ} \mathrm{C}\right)$ porous tungsten surface under ultra-high vacuum to vaporise the nonrefractory components of the particles. The resulting vapour is subsequently ionised using a $70 \mathrm{eV}$ electron impact (EI) to finally analyse the resultant ions with a quadrupole mass spectrometer (Jayne et al., 2000).

Data acquisition was carried out with the ACSM DAQ software (v. 1.4.4.5). The Q-ACSM data were corrected for a decrease in ion transmission at high $\mathrm{m}=\mathrm{z}(>55)$ according to a standard curve obtained by $\mathrm{Ng}$ et al. (2011). To correct for the decay of the detector amplification the airbeam $\mathrm{N}_{2}$ signal at $\mathrm{m}=\mathrm{z} 28$ was used (reference value: $\left.1 \times 10^{-7} \mathrm{~A}\right)$.

Data were treated according to (Ulbrich et al., 2009, section 3.1) to generate a matrix of masses for the corresponding time and mass-tocharge up to $\mathrm{m}=\mathrm{z} 100$ and associated error matrix.

The performance of the used Q-ACSM instrument used for this study was previously tested in an intercomparison where 13 individual QACSM were co-located during a two-week field campaign (Crenn et al., 2015; Fröhlich et al., 2015). The instrument used in this study (\#11) fulfilled the intercomparison z-score test $(-3>$ z-score $<3)$ and was among those with the closest values to the average of all tested instruments for both inorganic and organic fragments as shown in Figure S5.6 of Crenn et al. (2015). In the present study the ACSM calibration was carried out according to the Aerosol Chemical Speciation Monitor Data Acquisition Software Manual procedures (Aerodyne, 2010). Comparable experimental NO3 response factor (RF) and the NH4 and $\mathrm{SO} 2$ relative ionization efficiencies were observed before and after the monitoring campaign (Table S1).

\section{Source apportionment approach}

The identification and quantification of sources was accomplished using Positive matrix factorisation (PMF), a statistical factor analysis algorithm developed by Paatero and Tapper (1994) and Paatero (1997). The multilinear engine implementation (ME-2, Paatero, 1999) allows for the introduction of additional constraints (e.g. external factor profiles) to the algorithm. The algorithm has been widely used for source identification and quantification with offline and online datasets of inorganic or organic species (Belis et al., 2013; Viana et al., 2008; Zhang et al., 2011, 2017).

The PMF model solves the following mass balance equation $x_{i j}=\sum_{k=1}^{p}\left(g_{i k} f_{k j}\right)+e_{i j}$

Where $x$ is the measured quantity, $f$ is the factor profile, $g$ the temporal variability of each source and $e$ represent the residuals. The subscripts $i$ and $j$ correspond to each of the $n$ time steps and $m$ chemical species (e.g. trace elements or mass fragments), respectively. The subscript $k$ refers to the factors the number of which $(p)$ is defined by the user. Solution to Eq. (1) is reached by minimizing a goodness-of-fit parameter known as $\mathrm{Q}$ value (Eq (2)) which is the difference between measured $\left(x_{i j}\right)$ and modelled $\left(g_{i k} f_{k j}\right)$ quantities scaled by their uncertainties $\left(u_{i j}\right)$.

$Q=\sum_{i=1}^{n} \sum_{j=1}^{m}\left(\frac{x_{i j}-\sum_{k=1}^{p}\left(g_{i k} f_{k j}\right)}{u_{i j}}\right)^{2}$

One of the requirements for a dataset to be used in PM source apportionment with factor analytical methods is that the main chemical components representing a high share of the PM mass (organic fraction, major ions, elemental or black carbon) and a series of tracers (trace elements, organic markers) are included (Lucarelli et al., 2015; Belis et al., 2014). Commonly available offline datasets include a number of $24 \mathrm{~h}$ samples ranging from 60 to 100 (Hafner and Brown, 2005; Belis et al., 2014). Moreover, techniques measuring a wide range of markers with high time resolution (down to hours or minutes) provide evidence for a better understanding of the processes involving organic compounds, to characterise sources more comprehensively from the chemical and dimensional points of view and to identify sources associated with short lived processes (not detectable with $24 \mathrm{~h}$ averaged samples). Examples of this kind of techniques are the aerosol mass spectrometer (AMS, Jayne et al., 2000) and the related aerosol chemical speciation monitor (Q-ACSM, Ng et al., 2011) to analyse organic mass spectra. In addition, rotating drums (Peré-Trepat et al., 2007) or streakers (Crespo et al., 2012; Moreno et al., 2013) are commonly used to obtain (offline) high time resolution records of elemental composition. Combining online organic and inorganic datasets to be used as input for receptor models could be problematic when the uncertainties and the number of species are not homogeneous among the different techniques. Nevertheless, online high resolution with a complete organic and inorganic characterisation of the aerosol is a new receptor models' frontier that deserves more investigation.

Considering the limited previous knowledge of source profiles with a high number of heterogeneous components (in our case 87 species) a multi-step source apportionment approach was adopted in this study, to better monitor the impact of combining data from different size fractions (NR-PM $\mathrm{P}_{1}$ and $\mathrm{PM}_{2.5}$ ) and with different uncertainty estimation methods. The steps are as follows:

Step 1. PMF run with a $6 \mathrm{~h}$ time resolution offline dataset, including OC/EC, major ions and trace elements, to provide a list of sources with traditional chemical profiles, simplified source diurnal variations and time trends following an approach consistent with previous studies in the Po Valley (Larsen et al., 2012; Vecchi et al., 2009).

Step 2. PMF run with hourly online Q-ACSM data (fragments $\mathrm{m} / \mathrm{z}$ ) to obtain a picture of the sources contributing to the organic NR-PM 
fraction with chemical profiles coherent with literature and previous studies carried out with the same technique in the Po Valley (e. g. Bressi et al., 2016).

Step 3. PMF run with hourly online Xact 625 trace elements and QACSM inorganic ions to determine the sources and contributions resulting from the use of the inorganic components of PM.

Step 4. PMF run with hourly combined Xact 625 and Q-ACSM datasets (major ions, $\mathrm{m} / \mathrm{z}$ of organic fragments and trace elements) using the results of the previous steps as reference to support the identification of sources and the estimation of their contributions to PM. In this step a series of tests (section 4.3.3) to harmonise the uncertainties of the abovementioned families of compounds used in the analysis were carried out.

To guarantee the robustness of the "combined" source apportionment every step was consistent with the previous ones (when appropriate), especially as regards the source chemical profiles. With the scheme followed in this study, the source apportionment carried out in steps 1 to 3 using well-known approaches and homogeneous input data served as a reference for the development of the source apportionment based on the "combined" dataset.

The US-EPA PMF5 application implementing the Multilinear Engine v2 (Paatero, 1999) was used for the source apportionment runs. The identification of the primary sources in steps 1 and 3 was confirmed by comparison with the source profiles of the SPECIATE (Simon et al., 2010; Hsu and Divita, 2014) and SPECIEUROPE repositories (Pernigotti et al., 2016) by means of the DeltaSA tool (Pernigotti and Belis, 2018). The average standardised identity distance (SID $\mathrm{k}=1$, Belis et al., 2015), where distances equal or below 1 are acceptable, was used to compare the chemical profiles.

The $\mathrm{m} / \mathrm{z}$ spectra obtained in step 2 (Q-ACSM) were validated by comparison with reference spectra from a previous study in a similar site of the Po Valley (Bressi et al., 2016) and from the literature: MILAGRO (DeCarlo et al., 2010) and MEGACITY (Crippa et al., 2013) projects.

\subsection{Online datasets input uncertainty}

The uncertainty of the Xact 625 measurements depends on a series of factors: a) the relationship between the atmospheric concentration of the elements and the instrument MDL (higher for levels < 3.3x MDL), b) line interferences in multi-element samples and self-absorption for the lightest elements and c) the length of the sampling time (inversely proportional). The uncertainties of measurements are determined for every single concentration value by comparison with internal standards (at every measurement cycle and daily) during the instrument operation taking into account the above mentioned variables. In addition, laboratory experiments with NIST standards report additional uncertainty $<5 \%$ due to fitting errors and uncertainties in the internal standards (Furger et al., 2017). In this study, Xact 625 uncertainties were calculated for each value of each element under the corresponding energy condition (EC) and standard tube ( $\mathrm{Al}, \mathrm{Pd}, \mathrm{Cu}$ ) used for the measurement with (regression) parameters fitted in automatic daily calibrations. Ca, Ti, V, Cr, Mn, Sb and Ba correspond to EC1 (25 kV with Al standard); $\mathrm{Fe}, \mathrm{Co}, \mathrm{Ni}, \mathrm{Cu}, \mathrm{Zn}, \mathrm{As}, \mathrm{Se} \mathrm{Hg}$, $\mathrm{Tl}$ and $\mathrm{Pb}$ to EC2 (48 kV with Pd standard) and Pd, Ag, Cd; and Sn to (EC3 $48 \mathrm{kV}$ with Cu standard).

The Q-ACSM uncertainties were calculated according to Ulbrich et al. (2009) with the Igor Pro (Wavemetrics Inc) local tool (v. 1.5.3.2) for Q-ACSM data treatment and export of PMF matrices. The initial error values were calculated as the standard deviation of the Poisson distribution of the detected ions in a given time period convolved with a Gaussian curve describing the distribution of the electrical pulse areas (Allan et al., 2003). A minimum uncertainty was attributed to every single variable on the basis of the length of the sampling time. The error of a 3-point smoothing of the $\mathrm{m} / \mathrm{z}$ time series was added in quadrature to decrease the data noise. Finally, fragmentation tables (Allan et al., 2004) were used to account for the contribution from gaseous species and for the fragmentation that certain molecules (e.g. ammonium nitrate, ammonium sulphate, polycarboxylic acids) undergo when vaporising at high temperatures. This is needed to correct the decrease in the $\mathrm{m} / \mathrm{z}$ peaks of bigger molecules and corresponding increase in the lower $\mathrm{m} / \mathrm{z}$ peaks of the mass spectrum because of the presence of fragments of low molecular weight. For $30 \mathrm{~min}$ of averaging time (t30), the $3 \sigma$ detection limits for ammonium, organics, sulphate, nitrate, and chloride were $0.28 \mu \mathrm{g} / \mathrm{m}^{3}, 0.15 \mu \mathrm{g} / \mathrm{m}^{3}, 0.02 \mu \mathrm{g} / \mathrm{m}^{3}, 0.01 \mu \mathrm{g} / \mathrm{m}^{3}$, and $0.01 \mu \mathrm{g} / \mathrm{m}^{3}$, respectively ( $\mathrm{Ng}$ et al., 2011). The observed uncertainties were in line with the Q-ACSM reproducibility relative uncertainties observed in the ACSM intercomparison (Crenn et al., 2015): 9, 15, 19,

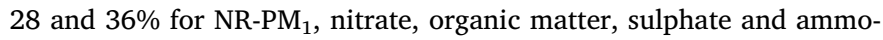
nium respectively.

To create an extensive input dataset for PMF, including organic and inorganic aerosol components (hereon "combined dataset"), it was necessary to pool measurements obtained with different analytical techniques. One of the most complex aspects when combining such kind of data is that the criteria to determine the analytical uncertainty may considerably vary between techniques and between instruments. Considering that in PMF every entry value is weighted by its uncertainty, significant differences in the uncertainties between techniques or instruments may overshadow the information relevant for the apportionment of sources. Moreover, in such a combined dataset, the number of markers deriving from different techniques could become unbalanced (e.g. AMS-like techniques produces organic spectra with a hundred or more $\mathrm{m} / \mathrm{z}$ while the number of trace elements (inorganic) vary between 20 and 30 ).

\subsection{Criteria adopted to harmonise the uncertainties of the online data}

In receptor modelling, there are different sources of error: random error, modelling error (bias), and rotational ambiguity (Paatero et al., 2014). The analytical procedures are one important source of random error. Also sampling and sample management may contribute to this kind of error. Moreover, modelling error arises in situations in which the RM assumptions are seriously infringed (e.g. wrong number of sources or variation of source profiles in time).

In step 4 of this study (section 4.3.3) we combined Xact 625 trace element measurements with Q-ACSM major ions and organic $\mathrm{m} / \mathrm{z}$ data. The analytical uncertainties of these measurements were used to calculate the input uncertainties for PMF according to Polissar et al. (1998) as follows:

$U_{i j}=\left\{\begin{array}{cl}\frac{5}{6} M D L_{i} & \text { if } x_{j} \leq M D L_{i} \\ \sqrt{u_{i}^{2} x_{j}^{2}+M D L_{i}^{2}} & \text { if } x_{j}>M D L_{i}\end{array}\right.$

Where $u_{i}$ are the analytical uncertainties and $U_{i j}$ the input uncertainties. The input uncertainties were considered as a first estimate of the total uncertainty of the input concentrations. To harmonise the uncertainties deriving from the different measurement techniques in the combined dataset, they were adjusted on the basis of the analysis of scaled residuals and the $\mathrm{Q}_{\text {true }} / \mathrm{Q}_{\text {exp }}$ ratios, both total and for every species, of the PMF runs (Paatero pers. comm.). To that end, after selecting the number of factors, the analytical uncertainties were increased so that the scaled residuals were evenly distributed around zero with a maximum of $5 \%$ absolute values (without sign) $>3$, the $\mathrm{Q}_{\text {true }} / \mathrm{Q}_{\exp }$ for every species did not exceed 2 and the overall $Q_{\text {true }} / Q_{\exp }$ ratio was at most few tenths above the unity. The increase of the starting analytical uncertainties was made for groups of species. When the distribution of the scaled residuals was skewed the uncertainties were adjusted only for lowest/highest values depending on the sign of the skewness (positive or negative). 


\section{Results}

\subsection{Comparison between online and offline trace elements analyses}

The online and offline elemental analyses were carried with two different techniques PIXE/PIGE and XRF, respectively. The good quality of the measurements is not under discussion considering that both datasets were generated following well established methods that include a series of quality checks as described in Chapter 2 . The objective of this chapter is to assess the comparability between online and offline elemental analyses to support the interpretation of the source apportionment results. To that end, the linear regression slope, the coefficient of determination $\left(R^{2}\right)$ and the absolute relative difference (ARD) were evaluated. Although a slope near unity and a high $\mathrm{R}^{2}$ are indicators of good agreement between measurements, this method has some limitations because samples with high concentrations may influence too much the regression. Therefore, the ARD indicator (Eq. (4)), was also used to test the relative difference between two sets of measurements sample by sample.

$A R D=100\left|\frac{\text { species }_{\text {on }}}{1 / 2\left(\text { species }_{\text {off }}+\text { species }_{\text {on }}\right)}-1\right|$

In this study, ARD less than $20 \%$ (for at least $2 / 3$ of the samples) and slope less than $20 \%$ different from unity with $\mathrm{R}^{2}$ higher than 0.8 were used as criteria to assess whether offline and online were in "good agreement" (G) (Yatkin et al., 2016). In addition, "poor agreement" (P) was attributed when ARD $>50 \%$, slope difference $>50 \%$ and $\mathrm{R}^{2}<0.5$. Results falling between good and poor agreement were allocated in an intermediate category regarded to as "acceptable agreement" (A).

The results of the comparability tests for the chemical species measured with both methods are reported in Table 2 and the time trends are shown in Fig. S1 of the supplementary material.

In order to compare the two datasets, the hourly online measurements were averaged to match the offline 6-h samples. Considering the low OM/OC winter ratios reported by Bressi et al. (2016) for a similar location of the Po Valley, the organic matter (Org) resulting from the QACSM was compared with the offline OC multiplied by the conversion factor 1.4 (Turpin and Lim, 2001). The gravimetric $\mathrm{PM}_{2.5}$ was compared with the sum of the chemical species obtained with the Q-ACSM. The organic matter and major ions showed good comparability between the offline and the online (Q-ACSM) in all the three test indicators, with the exception of the $\mathrm{R}^{2}$ in chloride, and consequently the overall comparability of these species was considered good (Table 2). A wider range of responses was observed in the 13 elements for which both offline and online measurements were available. Only $\mathrm{Fe}$ and $\mathrm{Cu}$ presented an overall good comparability with an $\mathrm{R}^{2}$ between 0.6 and 0.7 (Table 2). The majority of the elements (Ca, Ti, V, Cr, Mn, $\mathrm{Zn}$ and $\mathrm{Pb}$ ) presented an intermediate comparability as shown by their higher relative differences and dispersion of the data around the regression line. Finally, four elements (Ba, Ni, As and Se) showed low comparability between the two techniques mainly reflected by the poor fit of the linear regression curve. The low comparability of some elements could be attributed to high share of values falling below the Xact 625 MDLs:
Ba and As, or the of PIXE: V, As and Se (Table 1).

Good comparability is reported in the literature between offline methods: PIXE vs XRF and PIXE vs ICP-MS, for $\mathrm{Ca}, \mathrm{Ti}, \mathrm{Mn}, \mathrm{Fe}, \mathrm{Cu}$, and $\mathrm{Pb}$ in $\mathrm{PM}_{10}$ (Traversi et al., 2014; Yatkin et al., 2016). On the contrary, limited comparability between PIXE and XRF was observed for V, Cr, $\mathrm{Ni}, \mathrm{Zn}$ and Ba (Yatkin et al., 2016).

Moreover, good comparability between Xact 625 (online) and ICPOES/MS (offline) was reported for $\mathrm{S}, \mathrm{K}, \mathrm{Ca}, \mathrm{Ti}, \mathrm{Mn}, \mathrm{Fe}, \mathrm{Cu}, \mathrm{Zn}, \mathrm{Ba}, \mathrm{Pb}$ while poorer match was observed for: $\mathrm{V}, \mathrm{Cr}, \mathrm{Co}, \mathrm{Ni}, \mathrm{As}, \mathrm{Se}, \mathrm{Cd}, \mathrm{Sn}, \mathrm{Sb}$, $\mathrm{Hg}$ and Bi (Furger et al., 2017). A preliminary conclusion on the basis of this first part of the work is that the limited comparability between some of the offline and online trace element measurements observed in this study may be attributed to their low concentrations in the ambient air, that were often near or below the detection limit of the methods (As, Se, $\mathrm{V}$ and $\mathrm{Ba}$ ). Other factors contributing to the variability of results are: a) that, as shown by previous studies, the different methodologies are not fully comparable for all the elements (e.g. V, Cr, Ni, Zn and Ba) and $b$ ) that averaging of online data over the $6 \mathrm{~h}$ off-line samples was required for comparing them. In this regard, it must be taken into account that the comparisons available in the literature for this kind of data (Yatkin et al., 2016; Furger et al., 2017) refer to daily averages while in this study are used higher time resolutions that imply higher uncertainty for the XRF determinations due to the reduced sampling (= analytical) times.

\subsection{Source apportionment with offline data (step 1)}

The off-line dataset consisted of $61 \mathrm{PM}_{2.5} 6 \mathrm{~h}$ samples collected from $26 / 1$ to $19 / 2 / 2015$. The major chemical components (ions and carbonaceous fractions) of the offline and online were very similar in terms of relative composition. The total mass used for this run was the gravimetric $\mathrm{PM}_{2.5}$ mass $\left(41 \mu \mathrm{g} / \mathrm{m}^{3}\right)$.

The selected solution encompassed six sources: fresh biomass burning (BIOB, 33\%), aged biomass burning (AGED BIOB, 17\%), ammonium sulphate (AMS, 14\%), ammonium nitrate (AMN, 29\%), road dust and exhaust (TRAFFIC, 1.2\%), and iron/steel industry (STEEL, 4\%) (Fig. 2, Table 3). It was possible to detect a seventh sporadic source consisting of aged sea salt that was not considered for the purposes of this study because of its very low share of the total mass $(\ll 1 \%)$. The two biomass burning sources were identified on the basis of $\mathrm{K}^{+}$, elemental and organic carbon, chloride and $\mathrm{Zn}$. One of these source profiles contains $85 \%$ of the oxalate. In the literature oxalate is reported either as a primary or secondary pollutant. In European studies it has often been associated with both biomass burning emissions, as it is correlated with non-sea salt $\mathrm{K}^{+}$in winter, and to secondary aerosol because of its correlation with sulphate (Laongsri and Harrison, 2013; Yu et al., 2005). Moreover, winter secondary formation of oxalate and other diacids in wood burning plumes was reported in European continental background sites (Legrand et al., 2007). On the basis of this evidence, the biomass burning factors with and without oxalate have been allocated to aged and fresh fractions, respectively. The contemporary presence of fresh and aged biomass burning in PMF results has been reported in other locations (e.g. Perrone et al., 2018).

The fifth factor of this solution is a combination of a dust component as indicated by the presence of crust elements such as $\mathrm{Al}, \mathrm{Ca}, \mathrm{Ti}$ and $\mathrm{Fe}$

Table 2

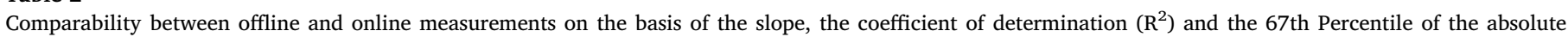

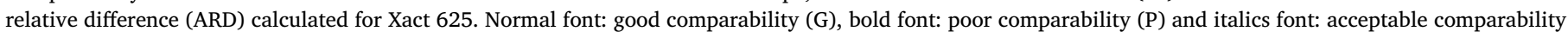
(A). Org = Q-ACSM organic matrix.

\begin{tabular}{|c|c|c|c|c|c|c|c|c|c|c|c|c|c|c|c|c|c|c|c|}
\hline & Org/OM & $\mathrm{SO}_{4}^{2-}$ & $\mathrm{NO}_{3}{ }^{-}$ & $\mathrm{NH}_{4}^{+}$ & $\mathrm{Cl}^{-}$ & $\mathrm{Ca}$ & $\mathrm{Ti}$ & $\mathrm{V}$ & $\mathrm{Cr}$ & Mn & $\mathrm{Ba}$ & $\mathrm{Fe}$ & $\mathrm{Ni}$ & $\mathrm{Cu}$ & $\mathrm{Zn}$ & As & $\mathrm{Se}$ & $\mathrm{Pb}$ & PM \\
\hline SLOPE & 1.0 & 0.9 & 0.8 & 1.0 & 1.0 & 0.5 & 0.7 & 1.1 & 0.7 & 1.2 & 0.0 & 1.2 & 0.4 & 1.1 & 0.7 & 0.5 & 1.6 & 0.5 & 1.0 \\
\hline $\mathrm{R}^{2}$ & 0.9 & 0.8 & 0.9 & 0.9 & 0.7 & 0.5 & 0.5 & 0.6 & 0.5 & 0.5 & 0.0 & 0.6 & 0.3 & 0.7 & 0.4 & 0.1 & 0.1 & 0.3 & 0.9 \\
\hline ARD 67th Per & 8 & 13 & 12 & 7 & 20 & 28 & 37 & 49 & 75 & 23 & 96 & 20 & 44.3 & 19.0 & 24.4 & 57.5 & 37.4 & 30.4 & 7.4 \\
\hline overall & G & G & G & G & G & $A$ & $A$ & $A$ & $A$ & $A$ & $\mathrm{P}$ & $\mathrm{G}$ & $\mathrm{P}$ & G & A & $\mathrm{P}$ & $\mathrm{P}$ & $A$ & G \\
\hline
\end{tabular}


INORGANIC SPECIES

ロ Step1

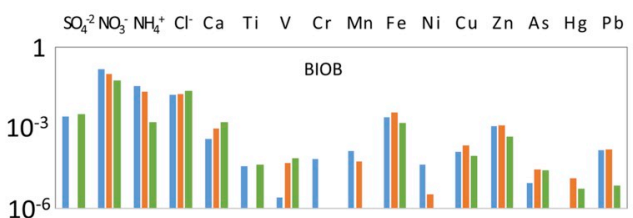

b

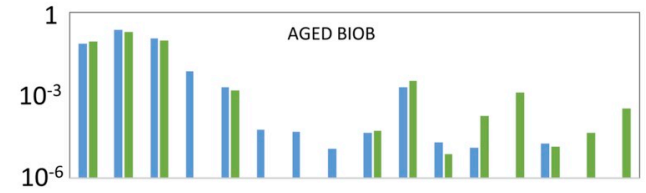

C

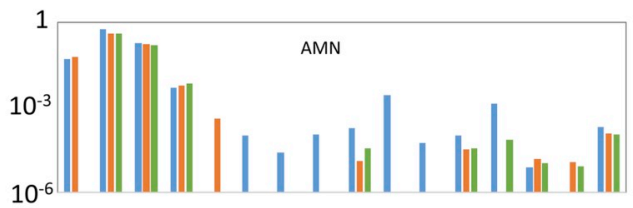

d

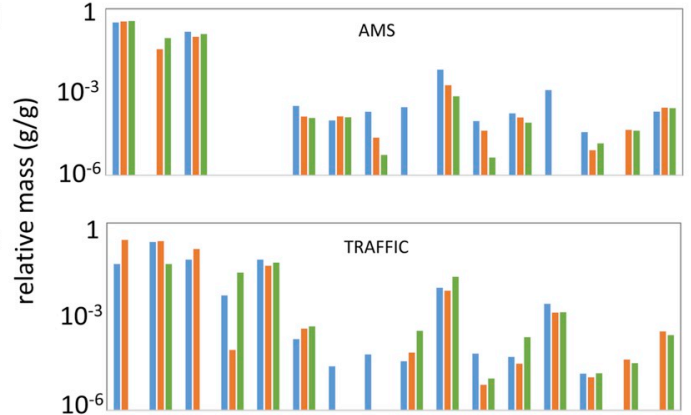

f

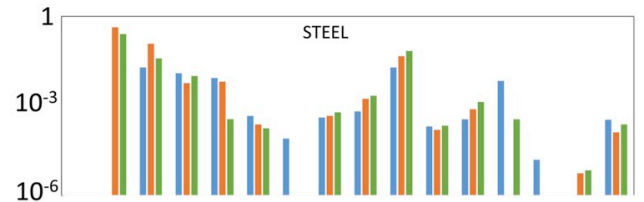

g

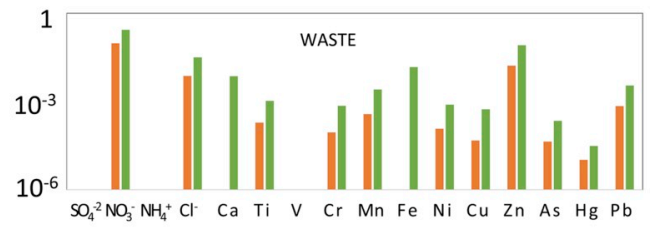

ORGANIC SPECIES

\Step 2 Step 4 Crippa et al.,2013 Bressi et al., 2016
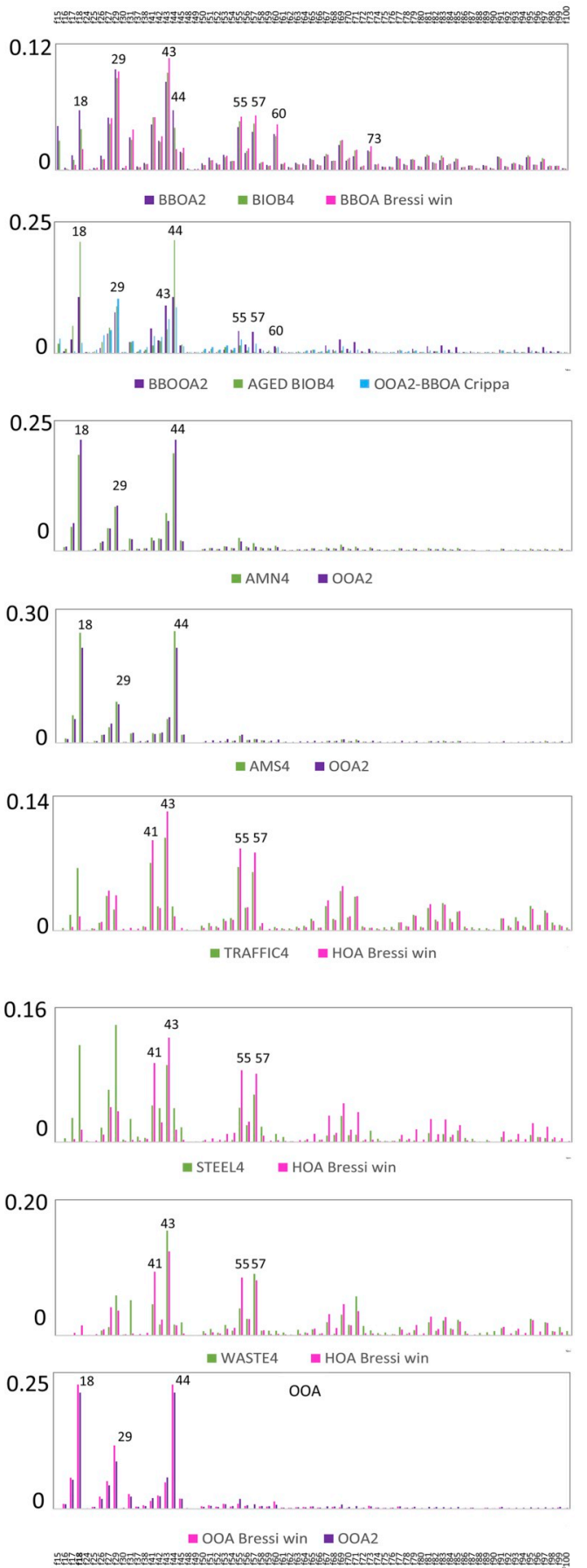

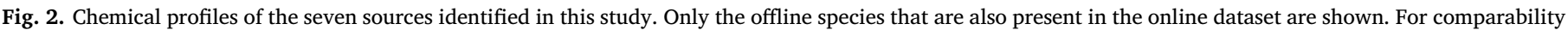

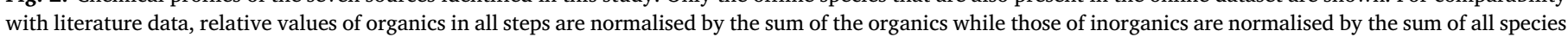
(the total mass of the profile).

and elements deriving from break abrasion such as $\mathrm{Zn}, \mathrm{Cu}, \mathrm{Ba}$ and $\mathrm{Mo}$ (Grigoratos and Martini, 2015). Nevertheless, components associated with exhaust are also present (OC, EC, nitrate), suggesting that the factor is likely to be attributed to the more comprehensive source category traffic, including both road dust and exhaust. The comparison with the chemical profiles in SPECIATE and SPECIEUROPE using the DeltaSA tool confirms the affinity of this factor with traffic (average SID $=0.95$ ). Also the allocation of the other primary sources: biomass burning and iron/steel industry has been confirmed by comparison with the abovementioned repositories (average SID $=0.93$ and 0.87 , respectively).

The simplified source diurnal variations (only four values each) were coherent with the identification of the sources (Fig. 3). The biomass burning and aged biomass burning source presented increasing concentrations during the evening and highest levels during the night. The road dust source presented highest values in the evening while the 
Table 3

Summary of the model set up used in the EPA-PMF 5 run in every source apportionment step.

\begin{tabular}{|c|c|c|c|c|}
\hline Step & STEP 1 & STEP 2 & STEP 3 & STEP 4 \\
\hline Duration & $26 / 1 \quad 16.00-20 / 210.00$ & $26 / 116.00-19 / 210.00$ & $26 / 1 \quad 16.00-19 / 210.00$ & $26 / 1 \quad 16.00-19 / 210.00$ \\
\hline Input data & OFFLINE & $\begin{array}{l}\text { ONLINE ACSM } \\
\text { ORGANICS }\end{array}$ & ONLINE XACT INORGANIC & ONLINE COMBINED DATASET \\
\hline \multirow[t]{2}{*}{ PM fraction } & $\mathrm{PM}_{2.5}$ & NR-PM ${ }_{1}$ & 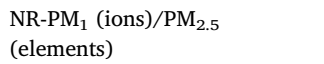 & NR-PM ${ }_{1}$ (ions, m/z)/PM 2.5 (elements) \\
\hline & $40.91 \mu \mathrm{g} / \mathrm{m}^{3}$ (gravimetric) & $\begin{array}{l}21.7 \mu \mathrm{g} / \mathrm{m}^{3} \text { (sum of } \\
\text { species) }\end{array}$ & $38.3 \mu \mathrm{g} / \mathrm{m}^{3}$ (sum of species) & $38.3 \mu \mathrm{g} / \mathrm{m}^{3}$ (sum of species) \\
\hline Factors & 6 & 3 & 6 & 7 \\
\hline Solution & BASE & BASE & BASE & CONSTRAINED \\
\hline \multirow{7}{*}{$\begin{array}{l}\text { Fac names and } \\
\text { contributions }\end{array}$} & BIOB: $33 \% ; 13.4 \mu \mathrm{g} / \mathrm{m}^{3}$ & BBOA: $34 \% ; 7.29 \mu \mathrm{g} / \mathrm{m}^{3}$ & BIOB: $36 \%, 13.7 \mu \mathrm{g} / \mathrm{m}^{3}$ & BIOB: $25 \% ; 9.6 \mu \mathrm{g} / \mathrm{m}^{3}$ \\
\hline & AGED BIOB: $17 \% ; 7.1 \mu \mathrm{g} / \mathrm{m}^{3}$ & $\begin{array}{l}\text { BB-OOA: } 28 \% ; 6.08 \mu \mathrm{g} / \\
\mathrm{m}^{3}\end{array}$ & AMN: $38 \%, 14.4 \mu \mathrm{g} / \mathrm{m}^{3}$ & AGED BIOB: $19 \% ; 7.1 \mu \mathrm{g} / \mathrm{m}^{3}$ \\
\hline & AMN: $29 \% ; 11.7 \mu \mathrm{g} / \mathrm{m}^{3}$ & OOA: $38 \% ; 8.22 \mu \mathrm{g} / \mathrm{m}^{3}$ & AMS: $17 \%, 6.5 \mu \mathrm{g} / \mathrm{m}^{3}$ & AMN: $32 \% ; 12.0 \mu \mathrm{g} / \mathrm{m}^{3}$ \\
\hline & AMS: $14 \% ; 5.5 \mu \mathrm{g} / \mathrm{m}^{3}$ & & TRAFFIC: $2 \%, 0.8 \mu \mathrm{g} / \mathrm{m}^{3}$ & AMS: $19 \% ; 7.0 \mu \mathrm{g} / \mathrm{m}^{3}$ \\
\hline & TRAFFIC: $3 \% ; 1.21 \mu \mathrm{g} / \mathrm{m}^{3}$ & & STEEL: $4 \%, 1.3 \mu \mathrm{g} / \mathrm{m}^{3}$ & TRAFFIC: $2 \% ; 0.8 \mu \mathrm{g} / \mathrm{m}^{3}$ \\
\hline & STEEL: $4 \% ; 1.83 \mu \mathrm{g} / \mathrm{m}^{3}$ & & WASTE: $3 \%, 1.2 \mu \mathrm{g} / \mathrm{m}^{3}$ & STEEL: $2 \% ; 0.9 \mu \mathrm{g} / \mathrm{m}^{3}$ \\
\hline & & & & WASTE: $1 \% ; 0.3 \mu \mathrm{g} / \mathrm{m}^{3}$ \\
\hline Species & 29: 20/9 (strong/weak) & 71: 67/4 (strong/weak) & 17: 17/0 (strong/weak) & 87: 87/0 (strong/weak) \\
\hline $\mathrm{S}=$ strong & $\begin{array}{l}\mathrm{S}: \mathrm{OC}, \mathrm{EC}, \mathrm{SO}_{4}{ }^{2-}, \mathrm{NO}_{3}{ }^{-}, \mathrm{NH}_{4}{ }^{+}, \\
\mathrm{Cl}^{-} \text {, Oxalate, } \mathrm{K}^{+}, \mathrm{Mg}^{+}, \mathrm{Ca}^{+}, \mathrm{Al}, \mathrm{Cr} \text {, } \\
\mathrm{Mn}, \mathrm{Fe}, \mathrm{Ni}, \mathrm{Cu}, \mathrm{Zn}, \mathrm{Br}, \mathrm{Rb}, \mathrm{Pb}\end{array}$ & $67 \mathrm{~m} / \mathrm{z}$ from $\mathrm{f} 15$ to $\mathrm{f} 100$ & $\begin{array}{l}\text { S:Org., } \mathrm{SO}_{4}{ }^{2-}, \mathrm{NO}_{3}{ }^{-}, \mathrm{NH}_{4}{ }^{+} \\
\mathrm{Cl}^{-}, \mathrm{Ca}, \mathrm{Ti}, \mathrm{V}, \mathrm{Cr}, \mathrm{Mn}, \mathrm{Ni}, \mathrm{Cu}, \\
\text { As. } \mathrm{Hg}, \mathrm{Pb}, \mathrm{Fe}, \mathrm{Zn}\end{array}$ & $\begin{array}{l}\text { Elements: } \mathrm{Ca}, \mathrm{Ti}, \mathrm{V}, \mathrm{Cr}, \mathrm{Mn}, \mathrm{Fe}, \mathrm{Ni}, \mathrm{Cu}, \mathrm{Zn}, \mathrm{As} \text {, } \\
\mathrm{Hg}, \mathrm{Pb}(12) ; \mathrm{m} / \mathrm{z} \text { from f15 to f100 (71); ions: } \\
\mathrm{SO}_{4}{ }^{2-}, \mathrm{NO}_{3}{ }^{-} \mathrm{NH}_{4}^{+}, \mathrm{Cl}^{-}(4)\end{array}$ \\
\hline $\mathrm{W}=$ weak & $\mathrm{W}: \mathrm{Na}, \mathrm{Ti}, \mathrm{V}, \mathrm{As}, \mathrm{Sr}, \mathrm{Y}, \mathrm{Zr}, \mathrm{Mo}, \mathrm{Ba}$ & W: f15, 24, 37, 49 & & \\
\hline Obs vs mod & $\begin{array}{l}\text { Slope < 0.5: Na, Al, Ti, V, As, Br, Sr, } \\
\text { Y }\end{array}$ & OK & Slope < 0.5: Ti, V, Cr, As, Pb & Slope < 0.5: Ti, V, Cr, As, Pb \\
\hline Scaled resid. & $>3: \mathrm{Cl}, \mathrm{Na}$ & $\begin{array}{l}>3: \mathrm{f} 31, \mathrm{f} 59, \mathrm{f} 60, \mathrm{f} 72, \\
\mathrm{f} 88, \mathrm{f} 90, \mathrm{f} 93, \mathrm{f} 95\end{array}$ & $>3: \mathrm{Ti}$ & $>$ 3: f90, f93, f95, Ti \\
\hline Time steps & 61 & 471 & 471 & 471 \\
\hline \multirow[t]{6}{*}{ Uncertainty input } & $2 \mathrm{x}$ all species & $0.8 \mathrm{x}: \mathrm{SO}_{4}{ }^{2-}$ & $0.8 \mathrm{x}: \mathrm{SO}_{4}^{2-}$ & $0.8 \mathrm{x}: \mathrm{SO}_{4}^{2-}$ \\
\hline & & $\begin{array}{l}1.5 x: \mathrm{NO}_{3}{ }^{-}, \mathrm{NH}_{4}^{+}, \mathrm{Cl}^{-}, \\
\text {f50 to f59 and f80 to f89/ }\end{array}$ & $\begin{array}{l}1.5 \mathrm{x}: \mathrm{NO}_{3}{ }^{-}, \mathrm{NH}_{4}{ }^{+}, \mathrm{Cl}^{-}, \mathrm{f} 80 \text { to } \\
\text { f100 }\end{array}$ & 1.5x: $\mathrm{NO}_{3}{ }^{-}, \mathrm{NH}_{4}{ }^{+}, \mathrm{Cl}^{-}, \mathrm{f} 45, \mathrm{f} 55, \mathrm{f} 71, \mathrm{f} 80$ to $\mathrm{f} 100$ \\
\hline & & 2x:f90 to $\mathrm{f} 100, \mathrm{Ti}$, As & 2x: f70 to $\mathrm{f} 79, \mathrm{Ti}$, As & $2 \mathrm{x}: \mathrm{f} 15, \mathrm{f} 43, \mathrm{f} 57, \mathrm{f} 72, \mathrm{f} 73, \mathrm{Ti}$, As \\
\hline & & $2.5 x: \mathrm{f} 60, \mathrm{f} 72, \mathrm{Ni}, \mathrm{Cu}$ & 2.5x: f60, $\mathrm{Ni}, \mathrm{Cu}$ & $2.5 x: \mathrm{f} 60, \mathrm{Ni}, \mathrm{Cu}$ \\
\hline & & $3 \mathrm{x}: \mathrm{V}, \mathrm{Ba}$ & $3 x: \mathrm{V}, \mathrm{Ba}$ & $3 \mathrm{x}: \mathrm{V}, \mathrm{Ba}$ \\
\hline & & $4 \mathrm{x}: \mathrm{Cr}, \mathrm{Mn}, \mathrm{Pb}$ & $4 \mathrm{x}: \mathrm{Cr}, \mathrm{Mn}, \mathrm{Pb}$ & $4 \mathrm{x}: \mathrm{Cr}, \mathrm{Mn}, \mathrm{Pb}$ \\
\hline \multirow[t]{2}{*}{$Q_{\text {rob }}-Q_{\text {true }}$} & $1113-1212$ & $30455-31988$ & $4205-5223$ & Base: 37374 - 40547 \\
\hline & & & & Constr: $37690-40724 \mathrm{dQ}=0.8 \%$ \\
\hline \multirow[t]{2}{*}{$\mathrm{Q}_{\text {true }} / \mathrm{Q}_{\exp }$} & Overall: 1.80 & Overall: 1.1 & Overall: 0.94 & Overall: 1.09 (base); \\
\hline & Species $>2: \mathrm{Cl}^{-}, \mathrm{Na}, \mathrm{K}+, \mathrm{Ca}+, \mathrm{Zn}$ & Species $>2$ : none & Species $>2: \mathrm{Ti}, \mathrm{Ni}, \mathrm{Pb}$ & Species > 2: 93, 95, Ti \\
\hline BS, DISP & BS OK, DISP OK & BS OK, DISP OK & BS OK, DISP OK & BS OK, DISP OK \\
\hline Constraints & NO & NO & NO & $\begin{array}{l}\text { BIOB:SO4/NH4 = 2; SO4/PM = 0.003; } \\
\text { AMN: f60 = } 1.4 \text { x f58; } \\
\text { TRAFFIC: } \mathrm{f} 44=\mathrm{f} 42 ; \mathrm{f} 60=1.6 \text { x f61; } \\
\text { STEEL: f44 = f42; f60 = } 1.6 \text { x f61; } \\
\text { WASTE: } \mathrm{f} 44=\mathrm{f} 42 ; \mathrm{f} 60=1.6 \text { x f61; }\end{array}$ \\
\hline
\end{tabular}

iron/steel industrial source showed the highest levels at noon. AMN and AMS presented rather flat diurnal patterns.

\subsection{Source apportionment with online data}

\subsubsection{SA of the organic fraction (step 2)}

A source apportionment run was carried using only the Q-ACSM components $(\mathrm{m} / \mathrm{z})$ of the online dataset for the same time window of the offline dataset (471 samples) (Fig. 2, Table 3). The total variable was the sum of the organic $\mathrm{m} / \mathrm{z}\left(22 \mu \mathrm{g} / \mathrm{m}^{3}\right)$. The best solution was the one with three sources representing primary biomass burning organic aerosol (BBOA, 34\%), biomass burning oxygenated organic aerosol (BBOOA, 28\%) and oxygenated organic aerosol (OOA, 38\%). A solution with a fourth factor including HOA was interpreted as a factor split because of its high similarity with the BBOA chemical profile.

The identification of the BBOA factor (key species: $f 29, f 43, f 60$ and f73) was confirmed by comparison with the one reported for the winter season by Bressi et al. (2016) for another suburban background location in the Po Valley (SID $=0.18$, Fig. 2a). Also the OOA factor (key species f18, f29 and f44) presented high similarity (SID $=0.31$ ) with the one reported by Bressi et al. (2016) (Fig. 2h). Since no BB-OOA source (key species: $\mathrm{f} 29, \mathrm{f} 44$ and $\mathrm{f} 60$ ) was reported in the latter study the chemical profile was validated with the ones reported by Crippa et al. (2013)
(SID $=0.61$, Fig. 2b) and DeCarlo et al. (2010) $($ SID $=0.64$, not shown).

Even though the chemical profiles of steps 1 and 2 could not be compared (because contain different markers), the analysis of $\mathrm{m} / \mathrm{z}$ spectra confirmed the identification of two sources associated with biomass burning: BBOA (fresh) and BB-OOA (aged), achieved using the offline dataset (step 1).

The BBOA diurnal variation showed increasing contributions (delta $13 \mu \mathrm{g} / \mathrm{m}^{3}$ ) from afternoon to night (17-23 $\mathrm{h}$ ) and minimum levels in the afternoon (14-17 h) (Fig. 3). In BB-OOA, a similar trend was observed with the difference that the diurnal excursion was narrower. On the other hand, the OOA presented no clear hourly trend with values arranged within a limited range (less than $3 \mu \mathrm{g} / \mathrm{m}^{3}$ ).

\subsection{2. $S A$ of the inorganic fraction (step 3)}

As a complement of step 2 a PMF run was also carried with only the inorganic compounds of the online dataset for the same time window of the offline dataset (471 samples) (Fig. 2, Table 3). The total variable in this step was the sum of all the chemical species $\left(38 \mu \mathrm{g} / \mathrm{m}^{3}\right)$. As in step 1 , six sources were identified: biomass burning (36\%), ammonium nitrate (38\%), ammonium sulphate (17\%), road dust/traffic (2\%), iron/ steel industry (1.3\%) and waste incineration (3\%). Unlike the offline (step 1) and online organic (step 2) datasets, in this run it was not 

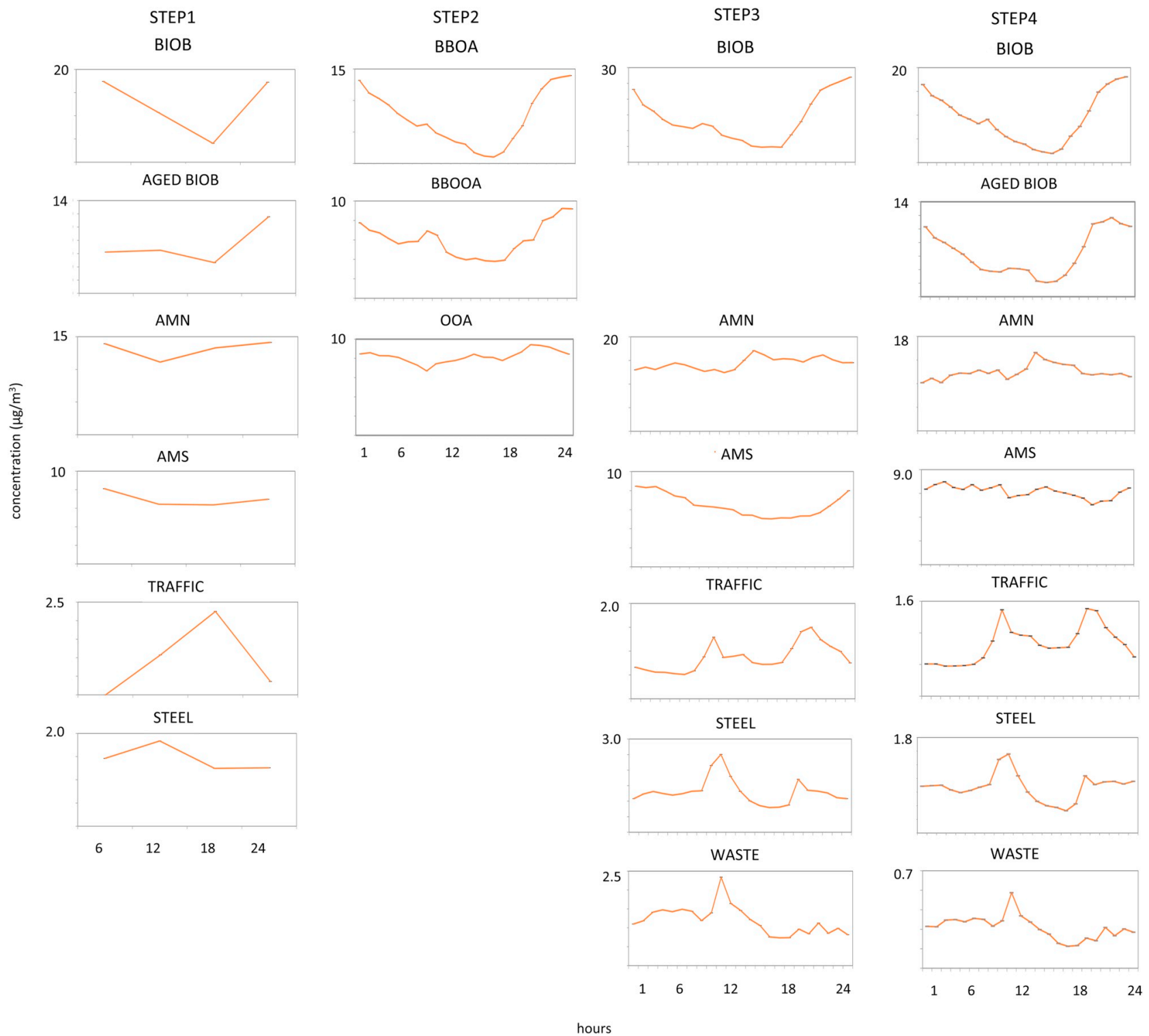

hours

Fig. 3. Source diurnal variations for the seven sources identified in this study. The curves in step 1 represent the average of $6 \mathrm{~h}$ samples while the others are hourly sample averages.

possible to distinguish fresh and aged fractions of biomass burning due to the lack of specific organic markers. On the other hand, in this step it was possible to better resolve the industrial source identified in the offline solution confirming the contribution from the steel industry (key species: Fe and $\mathrm{Mn}$ ) and extracting an additional source (key species: $\mathrm{Zn}, \mathrm{Cl}^{-}$) that has been attributed to waste thermal treatment. As in the previous steps, the identification of the sources biomass burning, road dust, steel industry and waste incineration was validated by comparison with the SPECIATE and SPECIEUROPE datasets using the DeltaSA tool (average SID $=0.96,0.96,0.90$ and 0.87 , respectively).

Unfortunately, Si and Al that are very useful for the identification of dust and road dust sources (Amato et al., 2016) and elemental carbon for the identification of traffic exhaust were not available in the online dataset used in this study. However, the availability of other elements typical of crustal material (Ca, Ti) and of brake emissions (Fe, Zn) made it possible to recognize the road dust fraction. In addition, the presence of ammonium nitrate and ammonium sulphate as in the traffic profiles of step 1 supported the identification of this factor as traffic source.

A check of the consistency between the source profiles belonging to comparable source categories obtained in this analysis and step 1 resulted in very good similarity for AMN (SID $=0.88$ ), AMS $(\mathrm{SID}=0.69), \quad$ road dust/traffic $($ SID $=0.70)$ and steel plant (SID $=0.72$ ). The sum of the profiles of the two biomass burning factors reported in step 1 was also comparable with the undivided biomass burning of this step (SID $=0.67$ ).

In this step, the biomass burning diurnal variations were comparable to those of BBOA in step 2 and as OOA in that step, AMN presented a very limited diurnal excursion. Also AMS presented limited diurnal variations with minimum values during the afternoon. Traffic presented two daily maxima corresponding to the rush hours while the two industrial sources showed a main daily peak before noon (Fig. 3).

\subsubsection{Combined dataset (step 4)}

The final solution obtained using the combined Q-ACSM and Xact 625 data for the same time window of the previous steps is presented in this section. Considering the complexity of the profiles encompassing species with different uncertainty estimation approaches (section 3.1 ) and the scarcity of such kind of profiles in the literature, a specific approach to ensure the soundness of the results was adopted. A solution was obtained after harmonising the uncertainties as described in section 
3.2. A constrained solution was then developed to fine tuning the source profiles taking as reference the chemical profiles obtained in steps 1 to 3 that were carried out using set of species whose uncertainties were derived with consistent methods (within each step). In addition, the three previous steps fulfilled widely accepted receptor models technical protocols (Belis et al., 2014; Hafner and Brown, 2005; Norris et al., 2014) and the resulting chemical profiles were validated by comparison with those in the literature. As a consequence, the output of step 4 was based on internal reference profiles derived from state-of-the art receptor model applications that either:

a) were obtained using a totally independent set of data (offline, step 1) for the same time window with the difference that the range of species and the time resolution was lower, or

b) covered the entire range of species (87) using the same type of variables and time resolution with the difference that were obtained in two separate runs (online, steps 2 and 3).

To prioritise solutions with chemical profiles coherent with to those obtained in steps 1 to 3 , constraints were applied in a post processing stage of the PMF analysis. The constraints were introduced as ratios between markers species taken from the profiles in the previous steps and from reference profiles in the literature (Table 3). The constrained ratios were:

\footnotetext{
- in BIOB, $\mathrm{SO}_{4} / \mathrm{NH}_{4}=2$ and $\mathrm{SO}_{4} / \mathrm{PM}=0.003$ (average of profiles in SPECIEUROPE and step 1);

- in TRAFFIC, STEEL and WASTE, $\mathrm{f} 44=\mathrm{f} 42$ and $\mathrm{f} 60=1.6 \times \mathrm{f} 61$ (average of HOA profiles from Bressi et al., 2016 and Sofowote et al., 2018);

- in AMN, f60 = 1.4 x f58 (average of OOA profiles from Bressi et al., 2016 and Sofowote et al., 2018).
}

The maximum $\mathrm{Q}$ variation for every single constraint was set to $0.5 \%$ and the increase in the global Q parameter was negligible $(0.8 \%)$. The comparison between the unconstrained and constrained chemical profiles is shown in Fig. S3 of supplementary material. The applied constraints did not altered the identity of the sources as confirmed by the conservation of the diurnal profiles (Fig. S4, supplementary material) while the allocation of the mass underwent minor changes ( $\leq 7 \%$ points) for the single sources (Fig. S5, supplementary material).

In this step seven factors were identified: fresh biomass burning (BIOB, 25\%), aged biomass burning (AGED BIOB, 19\%) ammonium nitrate (AMN, 32\%), ammonium sulphate (AMS, 19\%), road dust/ traffic (TRAFFIC, 2\%), iron/steel industry (STEEL, 2\%) and waste thermal treatment (WASTE, < 1\%) (Fig. 2, Table 3). A spreadsheet with the source profiles is provided in the supplementary material.

The combined analysis in step 4 confirmed the presence of fresh and aged biomass burning factors reported in steps 1 and 2. The chemical profile of the fresh biomass burning factor matched the one of the biomass burning in step 1 (SID $=0.82$ ), the one of BBOA factor in step $2($ SID $=0.15)$ and one in the literature (Bressi et al., 2016; SID $=0.12$; Fig. 2a). Also the chemical profile of the aged biomass burning from this step matched the one of the corresponding sources in step 1 $(\mathrm{SID}=0.76)$ and in step 2 (SID $=0.54$; Fig. $2 \mathrm{~b})$ and those in the literature (Crippa et al., 2013; DeCarlo et al., 2010; SID $=0.60$ and 0.69, respectively). The only difference was that in the $\mathrm{BB}-\mathrm{OOA}$ profile obtained in this step f18 and f44 peaks are higher than in the profiles used as reference.

The inorganic fraction of the AMN and AMS profiles were comparable with those observed in previous steps [SID: 0.90-0.55 in AMN and 0.79-0.37 in AMS for the offline (step 1) and online (step 3) datasets, respectively]. In these profiles the main species are ammonium nitrate and ammonium sulphate. Differences in some trace elements that are not key species for these factors were observed (Fig. 2c and d). In particular, $\mathrm{Ti}, \mathrm{V}, \mathrm{Cr}$, and $\mathrm{Zn}$ that were present in $\mathrm{AMN}$ obtained with the offline dataset (step 1) are missing in this step and in step 3. In the AMS factor the profiles were even more stable and the lack of match between offline and online only concerned $\mathrm{Mn}$ and $\mathrm{Zn}$. As for the organics, the sum of the $\mathrm{m} / \mathrm{z}$ spectra of AMN and AMS in this analysis presented a high affinity with the one of the OOA factor obtained in step 2 (SID $=0.45)$.

The remaining three factors added up to a relatively small share of the total mass. One of them was attributed to TRAFFIC (key inorganic species $\mathrm{Ca}, \mathrm{Fe}$ and $\mathrm{Zn}$; Fig. 2e) and the other two were associated with industrial activities (Fig. $2 \mathrm{f}$ and g): STEEL (key inorganic species Mn and $\mathrm{Fe}$ ) and WASTE (key inorganic species: $\mathrm{Zn}, \mathrm{Cl}^{-}$and Pb). TRAFFIC and STEEL profiles were comparable with those reported in step 1 (SID $=0.85$ and 0.60 , respectively). No WASTE source was identified in step 1 . The main differences with step 1 in TRAFFIC concerned ammonium sulphate, $\mathrm{V}, \mathrm{Cr}, \mathrm{Hg}$ and $\mathrm{Pb}$ while the STEEL profiles differed from the one in step 1 in nitrate, $\mathrm{Ca}$ and As. The similarity between the profiles in this run and those of step 3 (online inorganic) for these three sources was also satisfactory (SID $=0.60,0.42$ and 0.37 for TRAFFIC, STEEL and WASTE, respectively). The organic fractions of these three sources were characterised by primary combustion markers (e.g. f41, f43, f55 and f57). The SIDs between the HOA factor reported in Bressi et al. (2016) and TRAFFIC, STEEL and WASTE factors were $0.42,0.54$ and 0.59 respectively. The lack of a HOA factor in step 2 is likely due to the very little mass of this factor compared to the primary biomass burning. In step 4, the presence of organic and inorganic markers in the same dataset made it possible to identify a small HOA like fraction in traffic and industrial sources.

The limited contribution from TRAFFIC at this site is in line with its location in a small business area next to a dead end road $300 \mathrm{~m}$ from the closest main road. STEEL was associated with two steel plants located $19 \mathrm{~km}$ to the North-West ( $>100 \mathrm{kt}$ of steel/year). The presence of a WASTE source was associated with one incinerator (max. 220 ton/day; max. electric power $95 \mathrm{MWh}$ ) located $17 \mathrm{~km}$ to the East and a second one (max. 196 ton/day; max. electric power $7 \mathrm{MWh}$ ) located $40 \mathrm{~km}$ to the North-West.

The daily time profiles of the sources were coherent with those observed in steps 1 to 3 (Fig. 3). BIOB and AGED BIOB presented a steep increase in the evening. TRAFFIC showed two clear maxima corresponding to the rush hours while AMN and AMS underwent modest variations along the day. The two industrial sources presented the highest levels in the latest morning hours.

To check the consistency between the source apportionment derived from combined online dataset (step4, $1 \mathrm{~h}$ samples) with the one derived from the offline one (step 1, $6 \mathrm{~h}$ samples), in Fig. 4 left are compared the source contribution time series for the studied time window $(26 / 1$ to $19 / 2 / 2015)$. The comparison is limited to the sources that were present in both steps. In BIOB and AMN a very good match between the two steps in terms of phase and amplitude was observed (Fig. 4a,c). TRAFFIC contributions were near zero on 14th and 15th February which corresponds to the closure of the main streets for the traditional Carnival parade (Fig. 4e). Although trends and levels were quite coherent in AGED BIOB, AMS, TRAFFIC and STEEL, small biases (positive or negative) for short time windows were detected. Differences between the AGED BIOB trends of the two steps were observed especially during the Carnival celebrations (Fig. 4b). However, there is not enough evidence to associate this event with the biomass burning contributions. In the same period, the AMS contributions in step 4 presented higher values than in step 1 while on 17th - 19th February it was the contrary (Fig. 4d). Also TRAFFIC and STEEL present comparable trends in both steps, however, the amplitude of the curve in step 4 was higher compared to the one in step 1 in the former and the opposite is true for the latter (Fig. 4e and f). The differences may be due to the presence of HOA organic fraction in these sources in step 4 that was not present in step 1.

In Fig. 4 (right) the time series of step 4 are compared with external markers derived from the offline dataset and from fixed monitoring 
COMPARISON OFFLINE - ONLINE

a

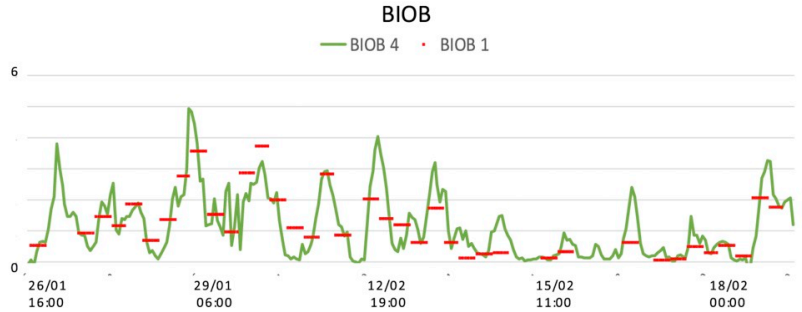

b
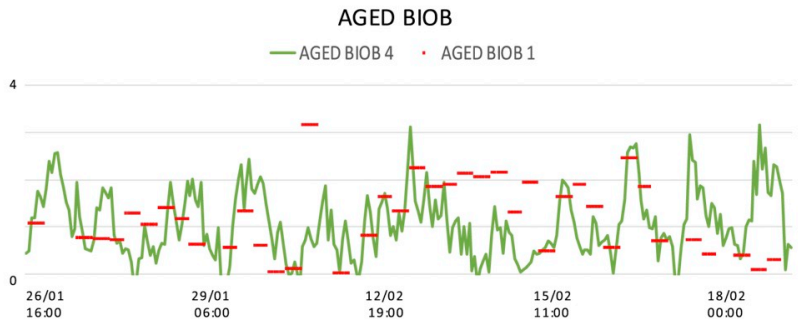

C AMN
$-A M N 4 \cdot$ AMN 1

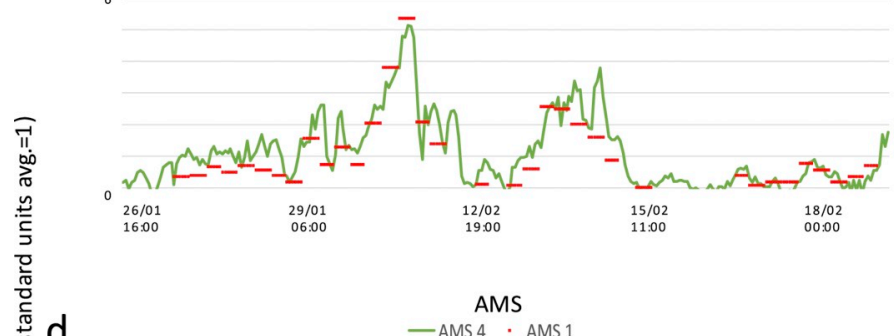

e

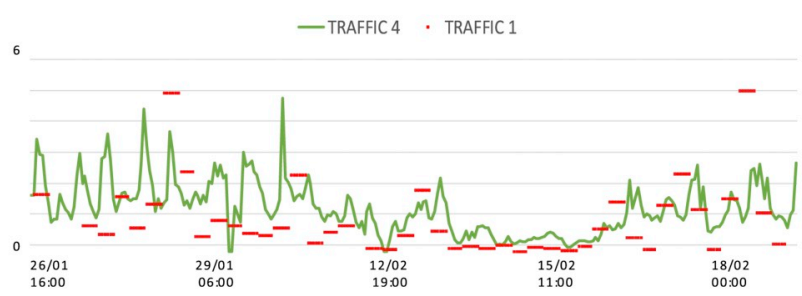

f

STEEL

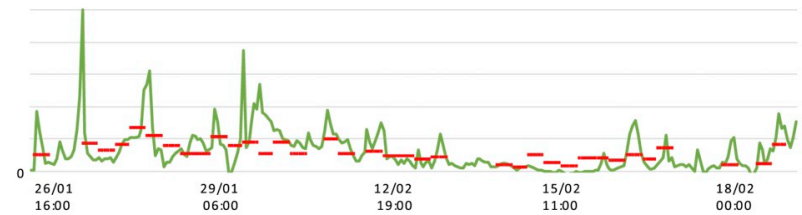

COMPARISON ONLINE - TRACERS

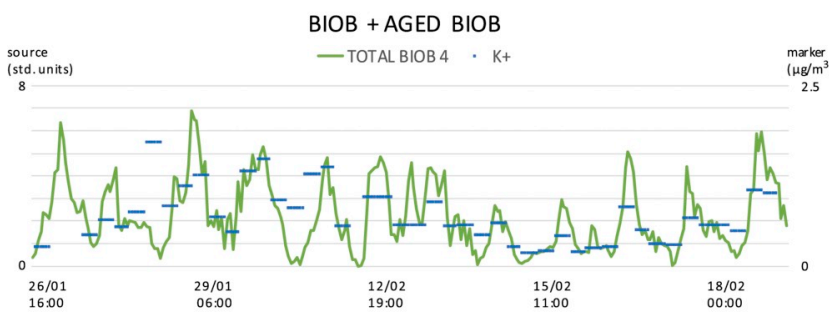

AGED BIOB
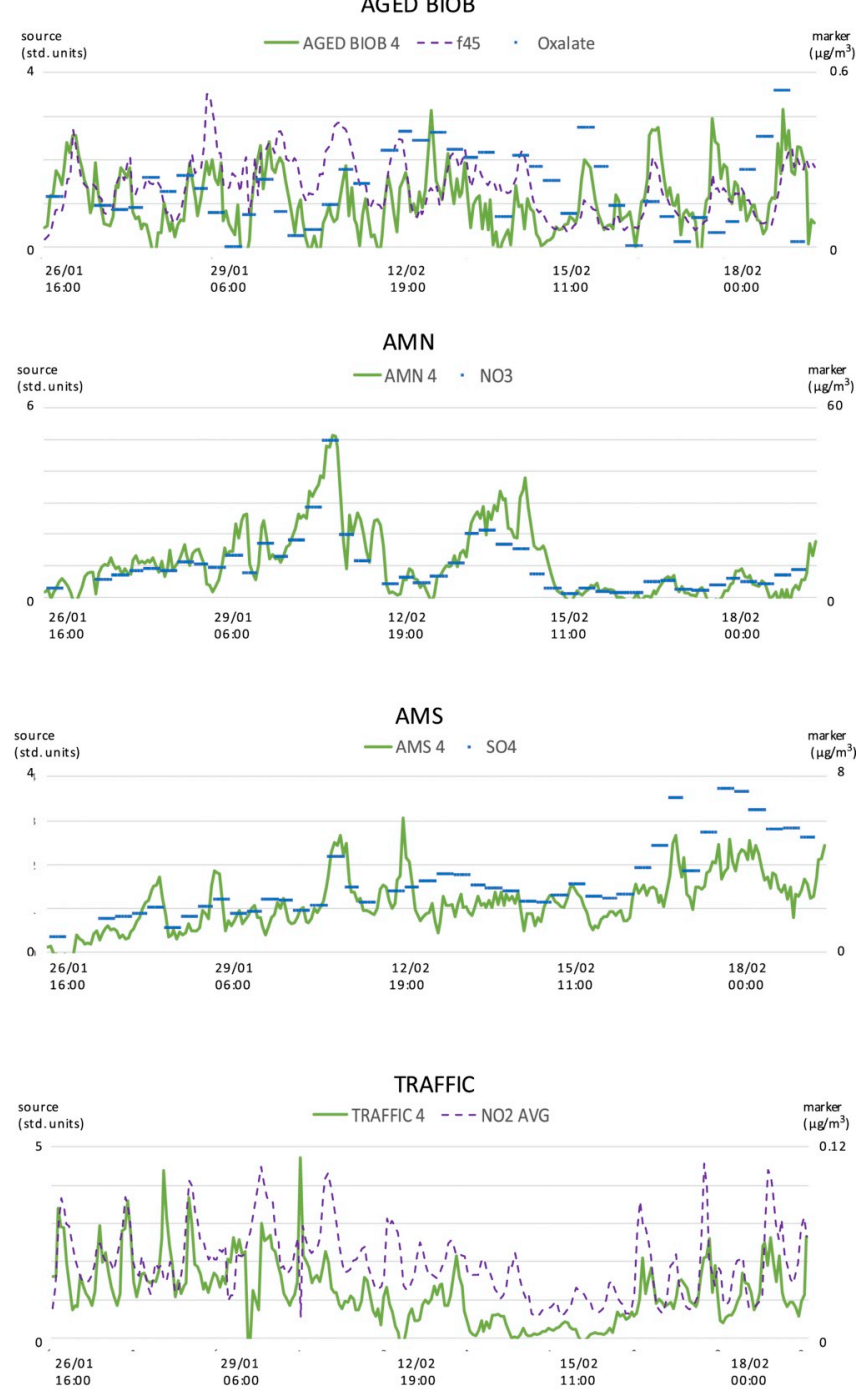

Fig. 4. Time trends of the sources identified in this study. Comparison of the online results with the offline sources and with independent markers. 
networks (Fig. 4 right). The BIOB matched the trend of $\mathrm{K}^{+}$(Fig. 4a). The bias between AGED BIOB and the levels of oxalate was very similar to the one observed between the trends of this source in steps 1 and 4 (Fig. 4b). Therefore, the abovementioned differences between the two steps may be due to the predominant role of this marker in step 1 while in step 4 the trend is influenced by a wider range of markers. This hypothesis is supported by the good correlation observed in step 4 between AGED BIOB and $\mathrm{f} 45$. This fragment derives from alfa cleavage with loss of alkyl radical ( $\mathrm{COOH})$ from mono- and low molecular mass di-acids (https://chem.libretexts.org/). A similar association between aged biomass burning source and $\mathrm{f} 45$ was reported by Sofowote et al. (2018). AMN and AMS trends match very well those of ammonium nitrate and ammonium sulphate concentrations in the offline dataset with the exception of the latest two days where the AMS in step 4 is lower confirming the underestimation observed in the comparison between the sources time series in these two steps. TRAFFIC presented a very good correlation with the averaged $\mathrm{NO}_{2}$ hourly trend of the two closest fixed monitoring stations of the relevant Regional Environmental Protection Agency (Fig. 4e).

\subsection{Discussion of the source apportionment approach}

This study aimed at developing a methodology to combine online organic and inorganic datasets with heterogeneous uncertainties for their use in source apportionment. Each of the source apportionment results obtained in steps 1 to 3 represent a complete and robust solution carried out using state-of-the-art methodologies and input data. Moreover, step 1 was based on a complete independent dataset. To guarantee the robustness of the results in step 4 (and take advantage of all the quality checks carried out in the execution of each previous step), its coherence with the previous ones was intentionally imposed. In addition, source profiles from the literature were used as an additional mean to ensure the soundness of the step 4 results. The consistency of the step 4 with the previous ones in terms of chemical profiles (Fig. 2), diurnal variations (Fig. 3) and time series (Fig. 4) demonstrates that a final combined result, which is consistent with the complete and robust solutions of steps 1-3 used as reference, was successfully achieved. This attainment and the coherence with the literature source profiles (SPECIATE, SPECIEUROPE and others) guarantee the robustness of the final solution and demonstrates the effectiveness of the approach used in this study.

The combination of high number of species and time resolution available in step 4 made it possible the identification in one single run of all the sources identified in the previous steps. In addition, in this step the sources were better characterised than in the previous ones because of the extended set of species and the source diurnal variations with hourly detail.

The mass apportioned to the different sources varied between the different steps of the analysis. Such differences are primarily due to different total variable used in every step (Table 3). A contribution to the variability of the output in step 4 with respect to the previous ones may be attributed to the different size fractions used: $\mathrm{PM}_{2.5}$ in the offline and online elemental analysis and $\mathrm{NR}-\mathrm{PM}_{1}$ for the online ions and $\mathrm{m} / \mathrm{z}$ spectra. Nevertheless, this discrepancy is considered to have a minor impact on the source apportionment results for a number of reasons. Firstly both fractions represent the same kind of aerosol (accumulation and smaller size modes) and their masses are highly correlated (Lagler et al., 2011). Secondly, during winter time in the Po Valley $\mathrm{PM}_{1}$ represents a very high fraction of the $\mathrm{PM}_{2.5}$ (Vecchi et al., 2008) as confirmed in our study where the average $\mathrm{PM}_{1} / \mathrm{PM}_{2.5}$ ratio was 0.9. Thirdly, the average chemical composition and the time series of the main components in the two size fractions, are comparable (Table 2 and Fig. S2). The differences between some of the trace elements have been attributed to the differences between the analytical methods used for the online and offline datasets. Finally, the homogeneity of $\mathrm{PM}_{1}$ and $\mathrm{PM}_{2.5}$ for the purposes of this study is supported by previous source apportionment work combining online and offline data where no significant differences were observed between Q-ACSM equipped with $\mathrm{PM}_{1}$ and $\mathrm{PM}_{2.5}$ lenses (Sofowote et al., 2018; Jeong et al., 2019).

Another important source of variation between steps is that the combination of different kinds of species into a single analysis influences the strength of the sources differently to analyses carried out with only a subset of them. This is mostly due to the different number of species representing the PM chemical fractions. For instance, in the offline dataset the organic fraction consisted of one single species: organic carbon, while in the combined dataset this fraction included 71 different species $(\mathrm{m} / \mathrm{z})$. Even though in this study the uncertainties of the different families of components were harmonised it is clear that the influence of the organic fraction in the allocation of the mass to the sources is stronger in the combined dataset (step 4) than in the offline dataset (step 1). Moreover, there were no online measures of black or elemental carbon in step 4 while this chemical component was available in step 1.

Finally, the differences observed between the chemical profiles and contributions obtained with offline and online datasets have been influenced by differences in the analytical determinations (section 4.1). Even if this source or error cannot be completely removed because depending on intrinsic differences between the analytical techniques, the most affected species were either excluded from the analysis (e.g. $\mathrm{Ba}, \mathrm{Sn}, \mathrm{Cd}, \mathrm{Ag}, \mathrm{Co}, \mathrm{Se}, \mathrm{Sb}, \mathrm{Tl}$ ) or strongly downweighted (e.g. $\mathrm{Cr}, \mathrm{V}, \mathrm{Ni}$, $\mathrm{Ti}, \mathrm{As}$ ). None of the marker species presented critical differences between offline and online measurements. The only exception is $\mathrm{Zn}$ that presented some discrepancies only at the beginning of the monitoring campaign (Fig. S2).

\section{Conclusions}

The study successfully developed a robust methodology to execute and validate a receptor model study combining high resolution organic and inorganic data derived from different online analysers with different uncertainty data treatment.

Good comparability between the offline and the online (Q-ACSM) in all the three test indicators was observed for major components of fine PM such as organic matter and major ions. On the other hand, the higher variability between offline (PIXE/PIGE) and online (Xact 625) trace elements observed in this study was attributed to the low concentrations of certain elements in the ambient air that resulted often near or below the method detection limits. Another source of variability is that the PIXE and XRF are not fully comparable for all the elements as suggested by Yatkin et al. (2016) for V, Cr, Ni, Zn and Ba.

Notwithstanding the abovementioned discrepancies in the analytical results, the approach adopted in this study led to the consistent combination of PM chemical components measured with analytical techniques that have different uncertainty estimation approaches. Such combination was possible thanks to the use of a protocol to harmonise the uncertainties based on the analysis of the PMF weighted residuals and Q/Qexp ratios. The robustness of the combined source apportionment was ensured through the consistency with an independent analysis based on an offline dataset, the use of source chemical profiles from the literature as reference, the soundness of the diurnal profiles and the coherence between the time series of the sources with external markers.

This study demonstrates that combining organic and inorganic markers with high time resolution supports a more comprehensive characterisation of the sources in terms of chemical composition and diurnal time profiles. This kind of analysis may, therefore, foster the identification of a higher number of sources because of the wider range of markers (organic and inorganic) and the possibility to identify sources associated with short lived processes that are not always detectable with $24 \mathrm{~h}$ averaged samples.

The source profiles reported in this study combining online ions, $\mathrm{m}$ / 
$\mathrm{z}$ and trace elements validated by comparison with external experimental and literature data are expected to contribute to the development of a pool of chemical profiles that could be used as reference for future studies. The developed methodology should be used to combine also online black carbon measurements to achieve an even more comprehensive set of markers.

\section{Acknowledgements}

The authors thank D. Moore and J. Berg (Cooper Environmental Services LLC, USA) who made available and supported the operation of the Xact ${ }^{\circledR} 625$ for this study. S. Solmi and F. Cercato, (Orion s. r.l., Italy) kindly provided logistic support during the data collection campaign. The data of the air quality monitoring network were kindly provided by the regional environmental protection agency of Veneto (ARPAV). Special thanks to M. Bressi and M. Trombetti for supporting the preparation of the data and figures, respectively.

\section{Appendix A. Supplementary data}

Supplementary data to this article can be found online at https:// doi.org/10.1016/j.aeaoa.2019.100046.

\section{References}

Aerodyne, 2010. Aerosol Chemical Speciation Monitor: Data Analysis Software Manual $\mathrm{ftp}: / / \mathrm{ftp}$.aerodyne.com/ACSM/ACSM Manuals/ACSM Igor_Manual.pdf, Accessed date: 15 February 2016.

Allan, J.D., Jimenez, J.L., Williams, P.I., Alfarra, M.R., Jayne, J.T., Coe, H., Worsnop, D.R., 2003. Quantitative sampling using an Aerodyne aerosol mass spectrometer 1. Techniques of data interpretation and error analysis. J. Geophys. Res. D Atmos. 108 AAC 1-1 - AAC 1-10.

Allan, J.D., Bower, K.N., Coe, H., Boudries, H., Jayne, J.T., Canagaratna, M.R., Millet, D.B., Goldstein, A.H., Quinn, P.K., Weber, R.J., Worsnop, D.R., 2004. Submicron aerosol composition at Trinidad Head, California, during ITCT 2K2: its relationship with gas phase volatile organic carbon and assessment of instrument performance. J. Geophys. Res. D Atmos. 109 (23), 1-16. https://doi.org/10.1029/2003JD004208.

Amato, F., Alastuey, A., Karanasiou, A., Lucarelli, F., Nava, S., Calzolai, G., Severi, M., Becagli, S., Gianelle, V.L., Colombi, C., Alves, C., Custódio, D., Nunes, T., Cerqueira, M., Pio, C., Eleftheriadis, K., Diapouli, E., Reche, C., Minguillón, M.C., Manousakas, M.-I., Maggos, T., Vratolis, S., Harrison, R.M., Querol, X., 2016. AIRUSE-LIFE +: a harmonized PM speciation and source apportionment in five southern European cities. Atmos. Chem. Phys. 16, 3289-3309. https://doi.org/10.5194/acp-16-32892016.

Baker, M.B., Peter, T., 2008. Small-scale cloud processes and climate. Nature 451 (7176), 299-300. https://doi.org/10.1038/nature06594.

Belis, C.A., Karagulian, F., Larsen, B.R., Hopke, P.K., 2013. Critical review and metaanalysis of ambient particulate matter source apportionment using receptor models in Europe. Atmos. Environ. 69, 94-108. https://doi.org/10.1016/j.atmosenv.2012.11. 009.

Belis, C.A., Larsen, B.R., Amato, F., Haddad, I. El, Favez, O., Harrison, R.M., Hopke, P.K., Nava, S., Paatero, P., Prévôt, A., Quass, U., Vecchi, R., Viana, M., 2014. European Guide on Air Pollution Source Apportionment with Receptor Models.

Belis, C.A., Pernigotti, D., Karagulian, F., Pirovano, G., Larsen, B.R., Gerboles, M., Hopke, P.K., 2015. A new methodology to assess the performance and uncertainty of source apportionment models in intercomparison exercises. Atmos. Environ. 119, 35-44. https://doi.org/10.1016/j.atmosenv.2015.08.002.

Bressi, M., Cavalli, F., Belis, C.A., Putaud, J.P., Fröhlich, R., Martins Dos Santos, S., Petralia, E., Prévôt, A.S.H., Berico, M., Malaguti, A., Canonaco, F., 2016. Variations in the chemical composition of the submicron aerosol and in the sources of the organic fraction at a regional background site of the Po Valley (Italy). Atmos. Chem. Phys. 16 (20), 12875-12896. https://doi.org/10.5194/acp-16-12875-2016.

Brown, R.J.C., Jarvis, K.E., Disch, B.A., Goddard, S.L., Adriaenssens, E., Claeys, N., 2010. Comparison of ED-XRF and LA-ICP-MS with the European reference method of acid digestion-ICP-MS for the measurement of metals in ambient particulate matter. Accred Qual. Assur. 15, 493-502.

Calzolai, G., Chiari, M., Lucarelli, F., Nava, S., Portarena, S., 2010. Proton induced c-ray emission yields for the analysis of light elements in aerosol samples in an external beam set-up. Nucl. Instrum. Methods B 268, 1540-1545.

Calzolai, G., Lucarelli, F., Chari, M., Nava, S., Giannoni, M., Carraresi, I., Prati, P., Vecchi, R., 2015. Improvements in PIXE analysis of hourly particulate matter samples. Nucl. Instrum. Methods Phys. Res. Sect. B Beam Interact. Mater. Atoms 363, 99-104. https://doi.org/10.1016/j.nimb.2015.08.022.

Cavalli, F., Viana, M., Yttri, K.E., Genberg, J., Putaud, J.P., 2010. Toward a standardised thermal-optical protocol for measuring atmospheric organic and elemental carbon: the EUSAAR protocol. Atmos. Meas. Tech. 3 (1), 79-89. https://doi.org/10.5194/ amt-3-79-2010.

Chang, Y., Huang, K., Xie, M., Deng, C., Zou, Z., Liu, S., Zhang, Y., 2018. First long-term and near real-time measurement of trace elements in China's urban atmosphere: temporal variability, source apportionment and precipitation effect. Atmos. Chem Phys. 18, 11793-11812. https://doi.org/10.5194/acp-18-11793-2018.

Crenn, V., Sciare, J., Croteau, P.L., Verlhac, S., Fröhlich, R., Belis, C.A., Aas, W., Äijälä, M., Alastuey, A., Artiñano, B., Baisnée, D., Bonnaire, N., Bressi, M., Canagaratna, M., Canonaco, F., Carbone, C., Cavalli, F., Coz, E., Cubison, M.J., Esser-Gietl, J.K., Green, D.C., Gros, V., Heikkinen, L., Herrmann, H., Lunder, C., Minguillón, M.C., Močnik, G., O'Dowd, C.D., Ovadnevaite, J., Petit, J.E., Petralia, E., Poulain, L., Priestman, M., Riffault, V., Ripoll, A., Sarda-Estève, R., Slowik, J.G., Setyan, A., Wiedensohler, A., Baltensperger, U., Prévôt, A.S.H., Jayne, J.T., Favez, O., 2015. ACTRIS ACSM intercomparison - Part 1: reproducibility of concentration and fragment results from 13 individual Quadrupole Aerosol Chemical Speciation Monitors (Q-ACSM) and consistency with co-located instruments. Atmos. Meas. Tech. 8 (12), 5063-5087. https:// doi.org/10.5194/amt-8-5063-2015.

Crespo, J., Yubero, E., Nicolás, J.F., Lucarelli, F., Nava, S., Chiari, M., Calzolai, G., 2012 High-time resolution and size-segregated elemental composition in high-intensity pyrotechnic exposures. J. Hazard Mater. 241-242, 82-91.

Crilley, L.R., Lucarelli, F., Bloss, W.J., Harrison, R.M., Beddows, D.C., Calzolai, G., Nava, S., Valli, G., Bernardoni, V., Vecchi, R., 2017. Source apportionment of fine and coarse particles at a roadside and urban background site in London during the 2012 summer ClearfLo campaign. Environ. Pollut. 220, 766-778.

Crippa, M., DeCarlo, P.F., Slowik, J.G., Mohr, C., Heringa, M.F., Chirico, R., Poulain, L., Freutel, F., Sciare, J., Cozic, J., Di Marco, C.F., Elsasser, M., Nicolas, J.B., Marchand, N., Abidi, E., Wiedensohler, A., Drewnick, F., Schneider, J., Borrmann, S., Nemitz, E., Zimmermann, R., Jaffrezo, J.L., Prévôt, A.S.H., Baltensperger, U., 2013. Wintertime aerosol chemical composition and source apportionment of the organic fraction in the metropolitan area of Paris. Atmos. Chem. Phys. 13 (2), 961-981. https://doi.org/10. 5194/acp-13-961-2013.

DeCarlo, P.F., Ulbrich, I.M., Crounse, J., De Foy, B., Dunlea, E.J., Aiken, A.C., Knapp, D., Weinheimer, A.J., Campos, T., Wennberg, P.O., Jimenez, J.L., 2010. Investigation of the sources and processing of organic aerosol over the Central Mexican Plateau from aircraft measurements during MILAGRO. Atmos. Chem. Phys. 10 (12), 5257-5280. https://doi.org/10.5194/acp-10-5257-2010.

EN12341, 2014. Ambient Air - Ambient Air - Standard Gravimetric Measurement Method for the Determination of the PM10 or PM2,5 Mass Concentration of Suspended Particulate Matter.

EN16909, 2017. Ambient Air - Measurement of Elemental Carbon (EC) and Organic Carbon (OC) Collected on Filters.

Fang, T., Guo, H., Verma, V., Peltier, R.E., Weber, R.J., 2015. PM2.5; water-soluble elements in the southeastern United States: automated analytical method development, spatiotemporal distributions, source apportionment, and implications for heath studies. Atmos. Chem. Phys. 15, 11667-11682. https://doi.org/10.5194/acp-15-116672015.

Fröhlich, R., Crenn, V., Setyan, A., Belis, C.A., Canonaco, F., Favez, O., Riffault, V., Slowik, J.G., Aas, W., Aijälä, M., Alastuey, A., Artiñano, B., Bonnaire, N., Bozzetti, C., Bressi, M., Carbone, C., Coz, E., Croteau, P.L., Cubison, M.J., Esser-Gietl, J.K., Green, D.C., Gros, V., Heikkinen, L., Herrmann, H., Jayne, J.T., Lunder, C.R., Minguillón, M.C., MoÄnik, G., O'Dowd, C.D., Ovadnevaite, J., Petralia, E., Poulain, L., Priestman, M., Ripoll, A., Sarda-Estève, R., Wiedensohler, A., Baltensperger, U., Sciare, J., Prévôt, A.S.H., 2015. ACTRIS ACSM intercomparison - Part 2: intercomparison of ME2 organic source apportionment results from 15 individual, co-located aerosol mass spectrometers. Atmos. Meas. Tech. 8 (6), 2555-2576. https://doi.org/10.5194/amt8-2555-2015.

Furger, M., Minguillón, M.C., Yadav, V., Slowik, J.G., Hüglin, C., Fröhlich, R., Petterson, K., Baltensperger, U., Prévôt, A.S.H., 2017. Elemental composition of ambient aerosols measured with high temporal resolution using an online XRF spectrometer. Atmos. Meas. Tech. 10 (6), 2061-2076. https://doi.org/10.5194/amt-10-2061-2017.

Geiger, A., Cooper, J., Petterson, K., Yadav, V., 2015. Highly-time-resolved toxic airborne metals measurements for improved estimation of source directionality and human health exposure. In: Proceedings of the Air and Waste Management Association's Annual Conference and Exhibition. AWMA, pp. 2811-2825.

Grigoratos, T., Martini, G., 2015. Brake wear particle emissions: a review. Environ. Sci. Pollut. Control Ser. 22, 2491-2504.

Guieu, C., Loÿe-Pilot, M.D., Ridame, C., Thomas, C., 2002. Chemical characterization of the Saharan dust end-member; some biological implications for the western Mediterranean. J. Geophys. Res. 107. https://doi.org/10.1029/2001JD000582.

Hafner, H.R., Brown, S.G., 2005. Source Apportionment Using Positive Matrix Factorization of Volatile Organic Compounds at a Heavily Industrialized Monitoring Site in Houston, Texas.

Haywood, J., Boucher, O., 2000. Estimates of the direct and indirect radiative forcing due to tropospheric aerosols: a review. Rev. Geophys. 38 (4), 513-543. https://doi.org/ 10.1029/1999RG000078.

Hopke, P.K., 2009. In: Legge, A.H., Elsevier (Eds.), Chapter 1 Theory and Application of Atmospheric Source Apportionment, pp. 1-33.

Hsu, Y., Divita, F., 2014. SPECIATE 4.3: ADDENDUM TO SPECIATE 4.2 SPECIATION DATABASE DEVELOPMENT DOCUMENTATION. TranSystems|E.H. Pechan \& Associates - U.S. E.P.A., Springfield (VA) U.S.A.

Jayne, J.T., Leard, D.C., Zhang, X., Davidovits, P., Smith, K.A., Kolb, C.E., Worsnop, D.R., 2000. Development of an aerosol mass spectrometer for size and composition analysis of submicron particles. Aerosol Sci. Technol. 33 (1-2), 49-70. https://doi.org/10. 1080/027868200410840.

Jeong, C.-H., Wang, J.M., Hilker, N., Debosz, J., Sofowote, U., Su, Y., Noble, M., Healy, R.M., Munoz, T., Dabek-Zlotorzynska, E., Celo, V., White, L., Audette, C., Herod, D., Evans, G.J., 2019. Temporal and spatial variability of traffic-related PM2.5 sources: comparison of exhaust and non-exhaust emissions. Atmos. Environ. 198, 55-69. https://doi.org/10.1016/j.atmosenv.2018.10.038. 
Kanakidou, M., Seinfeld, J.H., Pandis, S.N., Barnes, I., Dentener, F.J., Facchini, M.C., Van Dingenen, R., Ervens, B., Nenes, A., Nielsen, C.J., Swietlicki, E., Putaud, J.P., Balkanski, Y., Fuzzi, S., Horth, J., Moortgat, G.K., Winterhalter, R., Myhre, C.E.L., Tsigaridis, K., Vignati, E., Stephanou, E.G., Wilson, J., 2005. Organic aerosol and global climate modelling: a review. Atmos. Chem. Phys. 5 (4), 1053-1123. https:// doi.org/10.5194/acp-5-1053-2005.

Kulmala, O., Laakso, L., Lehtinen, K.E.J., Riipinen, I., Dal Maso, M., Anttila, T., Kerminen, V.-M., Hõrrak, U., Vana, M., Tammet, H., 2004. Initial steps of aerosol growth. Atmos. Chem. Phys. Discuss. 4 (5), 5433-5454. https://doi.org/10.5194/acpd-4 5433-2004.

Lagler, F., Belis, C., Borowiak, A., 2011. A Quality Assurance and Control Program for PM2.5 and PM10 Measurements in European Air Quality Monitoring Networks. EUR Scientific and Technical Research Reports No. JRC65176.

Laongsri, B., Harrison, R.M., 2013. Atmospheric behaviour of particulate oxalate at UK urban background and rural sites. Atmos. Environ. 71, 319-326.

Larsen, B.R., Gilardoni, S., Stenström, K., Niedzialek, J., Jimenez, J., Belis, C.A., 2012. Sources for PM air pollution in the Po Plain, Italy: II. Probabilistic uncertainty characterization and sensitivity analysis of secondary and primary sources. Atmos. Environ. 50 (April), 203-213. https://doi.org/10.1016/j.atmosenv.2011.12.038.

Legrand, M., Preunkert, S., Oliveira, T., Pio, C.A., Hammer, S., Gelencsér, A., KasperGiebl, A., Laj, P., 2007. Origin of C 2 -C 5 dicarboxylic acids in the European atmosphere inferred from year-round aerosol study conducted at a west-east transect. J. Geophys. Res. 112, D23S07. https://doi.org/10.1029/2006JD008019.

Leibensperger, E.M., Mickley, L.J., Jacob, D.J., Chen, W.T., Seinfeld, J.H., Nenes, A., Adams, P.J., Streets, D.G., Kumar, N., Rind, D., 2012. Climatic effects of 1950-2050 changes in US anthropogenic aerosols-Part 1: aerosol trends and radiative forcing. Atmos. Chem. Phys. 12 (7), 3333-3348. https://doi.org/10.5194/acp-12-3333-2012.

Lelieveld, J., Evans, J.S., Fnais, M., Giannadaki, D., Pozzer, A., 2015. The contribution of outdoor air pollution sources to premature mortality on a global scale. Nature 525 (7569), 367-371. https://doi.org/10.1038/nature15371.

Lioy, P.J., Zelenka, M.P., Cheng, M.-D., Reiss, N.M., Wilson, W.E., 1989. The effect of sampling duration on the ability to resolve source types using factor analysis. Atmos. Environ. 23, 239-254 1967.

Lohmann, U., Feichter, J., 2004. Global indirect aerosol effects: a review. Atmos. Chem. Phys. Discuss. 4 (6), 7561-7614. https://doi.org/10.5194/acpd-4-7561-2004.

Lucarelli, F., Calzolai, G., Chiari, M., Giannoni, M., Mochi, D., Nava, S., Carraresi, L., 2014. The upgraded external-beam PIXE/PIGE set-up at LABEC for very fast measurements on aerosol samples. Nucl. Instrum. Methods Phys. Res. Sect. B Beam Interact. Mater. Atoms 318, 55-59.

Lucarelli, F., Nava, S., Calzolai, G., Chiari, M., Giannoni, M., Traversi, R., Udisti, R., 2015. On the autarchic use of solely PIXE data in particulate matter source apportionment studies by receptor modeling. Nucl. Instrum. Methods Phys. Res. Sect. B Beam Interact. Mater. Atoms 363, 105-111.

Lucarelli, F., Calzolai, G., Chiari, M., Nava, S., Carraresi, L., 2018. Study of atmospheric aerosols by IBA techniques: the LABEC experience. Nucl. Instrum. Methods Phys. Res. Sect. B Beam Interact. Mater. Atoms 417, 121-127.

Moreno, T., Kojima, T., Amato, F., Lucarelli, F., de la Rosa, J., Calzolai, G., Nava, S., Chiari, M., Alastuey, A., Querol, X., Gibbons, W., 2013. Daily and hourly chemical impact of springtime transboundary aerosols on Japanese air quality. Atmos. Chem. Phys. 13, 1411-1424.

Myhre, G., Samset, B.H., Schulz, M., Balkanski, Y., Bauer, S., Berntsen, T.K., Bian, H., Bellouin, N., Chin, M., Diehl, T., Easter, R.C., Feichter, J., Ghan, S.J., Hauglustaine, D., Iversen, T., Kinne, S., Kirkeväg, A., Lamarque, J.F., Lin, G., Liu, X., Lund, M.T., Luo, G., Ma, X., Van Noije, T., Penner, J.E., Rasch, P.J., Ruiz, A., Seland, Skeie, R.B., Stier, P., Takemura, T., Tsigaridis, K., Wang, P., Wang, Z., Xu, L., Yu, H., Yu, F., Yoon, J.H., Zhang, K., Zhang, H., Zhou, C., 2013. Radiative forcing of the direct aerosol effect from AeroCom Phase II simulations. Atmos. Chem. Phys. 13 (4), 1853-1877. https://doi.org/10.5194/acp-13-1853-2013.

Ng, N.L., Herndon, S.C., Trimborn, A., Canagaratna, M.R., Croteau, P.L., Onasch, T.B., Sueper, D., Worsnop, D.R., Zhang, Q., Sun, Y.L., Jayne, J.T., 2011. An Aerosol Chemical Speciation Monitor (ACSM) for routine monitoring of the composition and mass concentrations of ambient aerosol. Aerosol Sci. Technol. 45 (7), 770-784. https://doi.org/10.1080/02786826.2011.560211.

Niu, J., Rasmussen, P.E., Wheeler, A., Williams, R., Chenier, M., 2010. Evaluation of airborne particulate matter and metals data in personal, indoor and outdoor environments using ED-XRF and ICP-MS and co-located duplicate samples. Atmos. Environ. 44, 235-245.

Norris, G., Duvall, R., Brown, S., Bai, S., 2014. doi:EPA/600/R-14/108. EPA Positive M Atrix Factorization (PMF) 5.0 Fundamentals and User Guide, vol. 136.

Ovadnevaite, J., Ceburnis, D., Canagaratna, M., Berresheim, H., Bialek, J., Martucci, G., Worsnop, D.R., O'Dowd, C., 2012. On the effect of wind speed on submicron sea salt mass concentrations and source fluxes. J. Geophys. Res. Atmos. 117 (16), 1-11. https://doi.org/10.1029/2011JD017379.

Paatero, P., 1997. Least squares formulation of robust non-negative factor analysis. Chemometr. Intell. Lab. Syst. 37 (1), 23-35. https://doi.org/10.1016/S01697439(96)00044-5.

Paatero, P., 1999. The multilinear engine-a table-driven, least squares program for solving multilinear problems, including the n-way parallel factor Analysis model. J. Comput. Graph. Stat. 8 (4), 854-888. https://doi.org/10.1080/10618600.1999. 10474853.

Paatero, P., Tapper, U., 1994. Positive matrix factorization: a non negative factor model with optimal utilization of error estimates of data values. Environmetrics 5 (2), 111-126. https://doi.org/10.1002/env.3170050203.

Paatero, P., Eberly, S., Brown, S.G., Norris, G.A., 2014. Methods for estimating uncertainty in factor analytic solutions. Atmos. Meas. Tech. 7 (3), 781-797. https://doi. org/10.5194/amt-7-781-2014.
Park, S., Cho, S., Jo, M., Gong, B., Park, J., Lee, S., 2014. Field evaluation of a near-real time elemental monitor and identification of element sources observed at an air monitoring supersite in Korea. Atmospheric Pollution Research 5, 119-128. https:// doi.org/10.5094/APR.2014.015.

Peré-Trepat, E., Kim, E., Paatero, P., Hopke, P.K., 2007. Source apportionment of time and size resolved ambient particulate matter measured with a rotating DRUM impactor. Atmos. Environ. 41 (28), 5921-5933. https://doi.org/10.1016/j.atmosenv. 2007.03.022.

Pernigotti, D., Belis, C.A., 2018. DeltaSA tool for source apportionment benchmarking, description and sensitivity analysis. Atmos. Environ. 180 (March), 138-148. https:// doi.org/10.1016/j.atmosenv.2018.02.046.

Pernigotti, D., Belis, C.A., Spanó, L., 2016. SPECIEUROPE: the European data base for PM source profiles. Atmos. Pollut. Res. 7 (2), 307-314. https://doi.org/10.1016/j.apr. 2015.10.007.

Perrone, M.G., Vratolis, S., Georgieva, E., Torok, S., Sega, K., Veleva, B., Osán, J., Beslic, I., Kertesz, Z., Pernigotti, D., Eleftheriadis, K., Belis, C.A., 2018. Sources and geographic origin of particulate matter in urban areas of the Danube macro-region: The cases of Zagreb (Croatia), Budapest (Hungary) and Sofia (Bulgaria). Sci. Total Environ. (619-620), 1515-1529. https://doi.org/10.1016/j.scitotenv.2017.11.092.

Polissar, A.V., Hopke, P.K., Paatero, P., Malm, W.C., Sisler, J.F., 1998. Atmospheric aerosol over Alaska 2. Elemental composition and sources. J. Geophys. Res. D Atmos. 103, 19045-19057.

Pope III, C.A., Burnett, R.T., Thun, M.J., Calle, E.E., Krewski, D., Thurston, G.D., 2002. To fine particulate air pollution. J. Am. Med. Assoc. 287 (9), 1132-1141. https://doi. org/10.1001/jama.287.9.1132.

Putaud, J.P., Bergamaschi, P., Cavalli, F., Dell'Acqua, A., Douglas, K., Goded, I., Grassi, F., Gruening, C., Jensen, N.R., Lagler, F., Manca, G., Martins Dos Santos, S., Matteucci, M., Passarella, R., Pedroni, V., Pokorska, O., 2018. JRC-ispra Atmosphere - Biosphere - Climate Integrated Monitoring Station: 2016 Report. EUR 28974 EN. Publications Office of the European Union, Luxembourg. https://doi.org/10.2760/453600, JRC109424. ISBN 978-92-79-77198-9.

Seinfeld, J.H., Pandis, S., 2016. Atmospheric Chemistry and Physics: from Air Pollution to Climate Change, third ed. John Wiley, pp. 1152 ISBN: 978-1-118-94740-.

Simon, H., Beck, L., Bhave, P.V., Divita, F., Hsu, Y., Luecken, D., Mobley, J.D., Pouliot, G.A., Reff, A., Sarwar, G., Strum, M., 2010. The development and uses of EPA's SPECIATE database. Atmos. Pollut. Res. 1 (4), 196-206. https://doi.org/10.5094/ APR.2010.026.

Simoneit, B.R.T., Schauer, J.J., Nolte, C.G., Oros, D.R., Elias, V.O., Fraser, M.P., Rogge, W.F., Cass, G.R., 1999. Levoglucosan, a tracer for cellulose in biomass burning and atmospheric particles. Atmos. Environ. 33 (2), 173-182. https://doi.org/10.1016/ S1352-2310(98)00145-9.

Sofowote, U.M., Healy, R.M., Su, Y., Debosz, J., Noble, M., Munoz, A., Jeong, C.-H., Wang, J.M., Hilker, N., Evans, G.J., Hopke, P.K., 2018. Understanding the PM2.5 imbalance between a far and near-road location: results of high temporal frequency source apportionment and parameterization of black carbon. Atmos. Environ. 173, 277-288.

Traversi, R., Becagli, S., Calzolai, G., Chiari, M., Giannoni, M., Lucarelli, F., Nava, S., Rugi, F., Severi, M., Udisti, R., 2014. A comparison between PIXE and ICP-AES measurements of metals in aerosol particulate collected in urban and marine sites in Italy. Nucl. Instrum. Methods Phys. Res. Sect. B Beam Interact. Mater. Atoms 318, $130-134$.

Tremper, A.H., Font, A., Priestman, M., Hamad, S.H., Chung, T.-C., Pribadi, A., Brown, R.J.C., Goddard, S.L., Grassineau, N., Petterson, K., Kelly, F.J., Green, D.C., 2018. Field and laboratory evaluation of a high time resolution x-ray fluorescence instrument for determining the elemental composition of ambient aerosols. Atmos. Meas. Tech. 11, 3541-3557. https://doi.org/10.5194/amt-11-3541-2018.

Turpin, B.J., Lim, H., 2001. Species contributions to PM2.5 mass Concentrations : revisiting common assumptions for estimating organic mass species contributions to PM2.5 mass Concentrations . Revisiting Common Assumptions for Estimating Organic Mass 35 (1), 602-610. https://doi.org/10.1080/02786820119445. June.

Ulbrich, I.M., Canagaratna, M.R., Zhang, Q., Worsnop, D.R., Jimenez, J.L., 2009. Interpretation of organic components from positive matrix factorization of aerosol mass spectrometric data. Atmos. Chem. Phys. 9, 2891. https://doi.org/10.5194/acp9-2891-2009.

Vecchi, R., Chiari, M., D'Alessandro, A., Fermo, P., Lucarelli, F., Mazzei, F., Nava, S., Piazzalunga, A., Prati, P., Silvani, F., Valli, G., 2008. A mass closure and PMF source apportionment study on the sub-micron sized aerosol fraction at urban sites in Italy. Atmos. Environ. 42, 2240-2253. https://doi.org/10.1016/j.atmosenv.2007.11.039.

Vecchi, R., Bernardoni, V., Fermo, P., Lucarelli, F., Mazzei, F., Nava, S., Prati, P., Piazzalunga, A., Valli, G., 2009. 4-hours resolution data to study PM10 in a "hot spot" area in Europe. Environ. Monit. Assess. 154 (1-4), 283-300. https://doi.org/10. 1007/s10661-008-0396-1.

Viana, M., Kuhlbusch, T.A.J., Querol, X., Alastuey, A., Harrison, R.M., Hopke, P.K., Winiwarter, W., Vallius, M., Szidat, S., Prévôt, A.S.H., Hueglin, C., Bloemen, H., Wåhlin, P., Vecchi, R., Miranda, A.I., Kasper-Giebl, A., Maenhaut, W., Hitzenberger, R., 2008. Source apportionment of particulate matter in Europe: a review of methods and results. J. Aerosol Sci. 39, 827-849. https://doi.org/10.1016/j.jaerosci.2008.05. 007.

Viana, M., Reche, C., Amato, F., Alastuey, A., Querol, X., Moreno, T., Lucarelli, F., Nava, S., Calzolai, G., Chiari, M., Rico, M., 2013. Evidence of biomass burning aerosols in the Barcelona urban environment during winter time. Atmos. Environ. 72, 81-88. https://doi.org/10.1016/j.atmosenv.2013.02.031.

Visser, S., Slowik, J.G., Furger, M., Zotter, P., Bukowiecki, N., Canonaco, F., Flechsig, U., Appel, K., Green, D.C., Tremper, A.H., Young, D.E., Williams, P.I., Allan, J.D., Coe, H., Williams, L.R., Mohr, C., Xu, L., Ng, N.L., Nemitz, E., Barlow, J.F., Halios, C.H., Fleming, Z.L., Baltensperger, U., Prévôt, A.S.H., 2015. Advanced source 
apportionment of size-resolved trace elements at multiple sites in London during winter. Atmos. Chem. Phys. 15, 11291-11309. https://doi.org/10.5194/acp-1511291-2015.

Watson, J.G., Chen, L.W.A., Chow, J.C., Doraiswamy, P., Lowenthal, D.H., 2008. Source apportionment: findings from the U.S. supersites program. J. Air Waste Manag. Assoc. $58,265-288$.

Yatkin, S., Gerboles, M., Borowiak, A., 2012. Evaluation of standardless EDXRF analysis for the determination of elements on PM10 loaded filters. Atmos. Environ. 54, 568-582.

Yatkin, S., Belis, C.A., Gerboles, M., Calzolai, G., Lucarelli, F., Cavalli, F., Trzepla, K., 2016. An interlaboratory comparison study on the measurement of elements in PM10. Atmos. Environ. 125, 61-68. https://doi.org/10.1016/j.atmosenv.2015.10. 084.
Yu, J.Z., Huang, X.-F., Xu, J., Hu, M., 2005. When aerosol sulfate goes up, so does Oxalate: implication for the formation mechanisms of oxalate. Environ. Sci. Technol. 39, 128-133.

Yu, J., Yan, C., Liu, Y., Li, X., Zhou, T., Zheng, M., 2018. Potassium: a tracer for biomass burning in beijing? Aerosol Air Qual. Res. 18, 2447-2459. https://doi.org/10.4209/ aaqr.2017.11.0536.

Zhang, Q., Jimenez, J.L., Canagaratna, M.R., Ulbrich, I.M., Ng, N.L., Worsnop, D.R., Sun, Y., 2011. Understanding atmospheric organic aerosols via factor analysis of aerosol mass spectrometry: a review. Anal. Bioanal. Chem. 401 (10), 3045-3067. https://doi. org/10.1007/s00216-011-5355-y.

Zhang, Y., Cai, J., Wang, S., He, K., Zheng, M., 2017. Review of receptor-based source apportionment research of fine particulate matter and its challenges in China. Sci. Total Environ. 586, 917-929. 